\title{
Arquitetura e Espaço Escolar: reflexões acerca do processo de implantação dos primeiros grupos escolares de Curitiba $(1903-1928)^{*}$
}

\section{Architecture and school space: thoughts about the implantation process of the first school groups of Curitiba (1903-1928)}

\author{
Marcus Levy Albino Bencostta**
}

\begin{abstract}
Não há nada de novo em preferir olhar o mundo por meio de um microscópio em lugar de um telescópio. Na medida em que aceitamos que estamos estudando o mesmo cosmo, a escolha entre micro e macrocosmo é uma questão de selecionar a técnica apropriada. É significativo que atualmente mais historiadores achem útil o microscópio, mas isso não significa que eles rejeitem os telescópios como antiquados.
\end{abstract}

Eric HOBSBAWM (1998, p. 206)

\begin{abstract}
RESUMO
Este artigo apresenta algumas reflexões a respeito dos projetos arquitetônicos de edifícios destinados aos grupos escolares construídos na capital do estado do Paraná durante a fase de implantação desse tipo de escola na cidade (1903 - 1928). Para tanto, este estudo analisou diversas fontes, tais como: relatórios, plantas baixas,
\end{abstract}

\footnotetext{
* Este artigo é resultante de análises decorrentes do projeto: A Imagem Fotográfica no Estudo das Instituições Educacionais: Os Grupos Escolares de Curitiba (1903-1971), financiado pelo CNPq com bolsa produtividade de pesquisa (proc. 300574/99-1), auxílio financeiro para desenvolvimento de projeto individual de pesquisa (proc. 42009/01-1) e duas auxiliares de pesquisa (Annelise F. Leite e Daniela Conceição Stoebel) com bolsas de iniciação científica/ PIBIC.

** Doutor em História, Professor da Área Temática de História e Historiografia da Educação do Programa de Pós-graduação em Educação da Universidade Federal do Paraná. E-mail: marcus.levy@pesquisador.cnpq.br.
} 
fotografias escolares, jornais, procurando relacioná-las às discussões historiográficas acerca da cultura escolar.

Palavras-chave: Arquitetura Escolar; Grupos Escolares; História do ensino primário; Cultura Escolar.

\section{ABSTRACT}

This article presents some thoughts related to architectural projects destined to schoolhouses that were built in the capital of Paraná State during the implantation phase of this kind of school in the city (1903-1928). In order to that, this research analyzed many sources as reports, plans, school photographs, newspapers, trying to relate them to discussions about School Culture historiography.

Key-words: school architecture; schoolhouses; history of primary teaching; school culture.

No discurso daqueles que implantaram, no Brasil, o novo regime político em 1889, era preciso, além da justificação racional do poder, a fim de legitimar a República, construir uma nação pautada em valores que demonstrassem estar em definitivo sintonizados com as mudanças que o mundo moderno apresentava. Esse discurso, sem dúvida, sofreu o impacto de concepções elaboradas a partir das experiências civilizatórias norte-americana e européia, que inspiravam os políticos e intelectuais na construção de argumentos discursivos e práticas que enalteciam a República.

Dentre as várias representações e práticas que objetivavam estabilizar e eternizar a República, afirma MONARCHA (1999, p. 101-102), destacavam-se aquelas que diziam respeito à Instrução Pública, que naquele momento adquiriu características de uma quase religião cívica, cujo papel era dotar a sociedade de coesão através da educação do povo e da criança do novo regime.

Semelhante à III República Francesa, que, segundo CARVALHO (1990, p. 20), teria sido um dos modelos de inspiração, a natureza discursiva dos políticos da República brasileira defendia o desenvolvimento da Instrução como determinante para o aprimoramento da civilização. GAILLARD (2000), ao analisar a ação de Jules Ferry (Ministro da Instrução Pública e Presidente do Conselho da III República Francesa) na construção de uma escola verdadeiramente republicana, formadora de cidadãos, explica como esse esforço de escolarização se tornou uma das maiores mitologias da história contemporânea francesa.

O Século das Luzes, continua GAILLARD (2000, p. 42-43), foi colocado sob o selo da instrução, embora os filósofos, e em particular os enciclopedistas, não tenham elaborado uma doutrina sobre o assunto. O conjunto de conhecimentos e, portanto, da transmissão dos progressos do espírito humano é que foi colocado sob tal selo. ROUSSEAU (1762), na obra Emílio ou Da Educação, recusa a escola como lugar obrigatório de aprendizagem de saberes e preconiza uma harmonia entre espontaneidade natural e educação livresca. DIDEROT (1775), em seu Plano de uma Universidade, entusiasma-se ao propor uma educação pública em todas as ciências, iniciando o livro 
com o capítulo "Da Instrução" pela afirmação: "instruir uma nação é também civilizála". ${ }^{1}$ Entretanto, esses e outros pensadores afirmam a prioridade do conhecimento e sua difusão pelas escolhas revolucionárias. As primeiras dessas escolhas seriam a secularização da escola, o fim do monopólio eclesiástico e a atribuição da missão de escolarização ao Estado. Em segundo lugar, viriam a obrigatoriedade e a gratuidade, consideradas pela maioria dos filósofos das Luzes uma conseqüência lógica da escolha de um serviço público de Estado para assegurar a instrução. Em terceiro lugar, estaria a nova concepção dos conteúdos, menos voltados para a especulação e as humanidades e mais voltados para um saber mais utilitário.

Os idealizadores da III República Francesa entendiam que, na democracia, o homem deveria ser esclarecido. Sua emancipação implicava uma escola que estivesse livre da tutela da Igreja Católica, cuja doutrina oficial, enunciada por Pio IX, combatia os princípios de 1789 e a filosofia dos Direitos do Homem. A prioridade outorgada à educação, conforme afirmam GAULUPEAU, ROZINOEN e LAMINAUD (2001, p. 617), obedece, enfim, ao imperativo patriótico. Em uma década marcada pela forte personalidade de Jules Ferry, o ensino primário francês é profundamente remodelado, de modo que, em julho de 1881, a questão da gratuidade das escolas primárias é definitivamente regulamentada. Amplamente debatida, a Lei de 28 de Março de 1882 torna obrigatória a instrução elementar e instaura a laicidade do ensino nas escolas públicas. Em sala de aula, a moral e a instrução cívica substituem a prece e o catecismo. O novo entusiasmo trazido pelo Estado republicano gera frutos. De 1880 a 1900, a escola elementar francesa ganha perto de 700 mil inscritos, atingindo a quase totalidade das crianças em fase escolar.

Foi olhando para a experiência da escola francesa e os discursos elaborados por seus intelectuais da educação, que parte das autoridades de ensino da República brasileira procurou se assemelhar de maneira incompleta, especialmente quando propõem a institucionalização da escola graduada.

Ao voltar os olhares para a realidade brasileira dos fins do século XIX, uma questão merece ser tencionada, qual seja, o que caracterizava esta escola graduada como uma instituição que se diferenciava daquela existente no período monárquico? Quais alterações estiveram ali presentes que proporcionaram a composição de um discurso que a denominava de instituição sintonizada com as modernas pedagogias existentes no mundo da educação civilizada?

A construção de edifícios específicos para os grupos escolares foi uma preocupação das administrações dos Estados que tinha no urbano o espaço privilegiado para a sua edificação, em especial, nas capitais e cidades prósperas economicamente. Em regra geral, a localização dos edifícios escolares deveria funcionar como ponto de destaque na cena urbana, de modo que se tornasse visível, enquanto signo de um ideal republicano, uma gramática discursiva arquitetônica que enaltecia o novo regime.

\footnotetext{
${ }^{1}$ Para um aprofundamento das questões educacionais no debate iluminista consultar BOTO, C. A Escola do Homem Novo. Entre o Iluminismo e a Revolução Francesa. São Paulo: Ed. da Unesp, 1996.
} 
BENCOSTTA, M. L. A. Arquitetura e espaço escolar: reflexões ...

Uma vez que a organização dos grupos escolares estabelecia a reunião de várias escolas primárias de uma determinada área em um único prédio, a administração pública entendeu ser um benefício financeiro aos seus cofres o fato de não ter que arcar com os aluguéis das diversas casas que abrigavam as escolas isoladas. Portanto, foi necessário desenvolver projetos que organizassem o espaço escolar a fim de constituir atividades que se adequassem às novas metodologias de ensino propaladas pelo discurso de uma moderna pedagogia. Todavia, é preciso reconhecer que esse investimento dos Estados não correspondeu às expectativas de um discurso que propunha a restauração da sociedade por meio da educação.

\section{A experiência da Escola Graduada com os grupos escolares na cidade de Curitiba}

No Paraná do início do século XX, o debate sobre a necessidade de projetos específicos para a Instrução Pública demonstra certa preocupação das autoridades de ensino em discutir um formato idealizado de escola primária. Nesse sentido, o Presidente do Estado, Francisco Xavier da Silva, fez publicar, em 1901, um novo regulamento da Instrução Pública.

De olho na experiência paulista, Xavier da Silva considerava que o atraso do ensino primário só poderia ser resolvido com o correr do tempo, através da proposta dos grupos escolares. A escola graduada era um novo modelo superior em vantagens às escolas isoladas, principalmente pela facilidade de fiscalização.

Estas causas do atraso do ensino só poderão ser removidas com o correr do tempo, convindo, entretanto, que aproveitemos o que de bom mostra a alheia experiência. Os grupos escolares têm provado bem. Adotemos tão útil e proveitosa instituição, primeiramente na capital, reunindo em um ou mais grupos, convenientemente distribuídos, as escolas aqui existentes, confiando a fiscalização de cada um deles a um diretor ou inspetor bem renumerado, com obrigações definidas em regulamento. (PARANÁ, 1901, p. 5)

Utilizando os pressupostos da administração, o presidente do Estado atentava também para a questão da vantagem econômica do agrupamento das escolas. "Em vez das escolas funcionarem em casas diversas, que custam alto o aluguel, passarão a funcionar em um só edifício, que reúna todas as condições exigidas pela higiene. E mais tarde, quando for possível, novos grupos se irão estabelecendo em outras localidades." (PARANÁ, 1901)

A iniciativa paulista de organização do ensino elementar público, através dos grupos escolares, iniciado nos fins do século XIX, certamente instigou as demais unidades da federação republicana em adotar, em níveis diferenciados, a experiência desse tipo de escola em seus Estados.

Na Curitiba republicana, como afirma TRINDADE (1996, p. 21), a escola pública primária foi constantemente colocada em pauta nas questões educacionais, muito por 
conta da ação direta dos inspetores, delegados, fiscais e diretores gerais de ensino que cobravam insistentemente ao Estado a construção de edifícios específicos às práticas escolares. Este tipo de preocupação se percebe, ainda em 1910, na exposição do Diretor Geral Interino de Instrução Pública, Jaime Dormund dos Reis, destinado ao Secretário do Interior, Justiça e Instrução Pública:

Em um Estado novo como o nosso, ávido de progresso, onde se aninham corações e espíritos sempre prontos aos vôos gigantescos do aperfeiçoamento, onde a natureza foi pródiga em materiais vegetais e minerais próprios para construções civis, materiais esses que são adquiridos por módico preço; com facilidade se iniciaria a transformação, neste particular, da Instrução Primária, dando-se a cada cadeira, um prédio próprio, com o conforto necessário, vasado nos moldes indicados pela ciência, com mobiliário e asseio capazes de bem influir sobre o desenvolvimento físico e moral das crianças que nela busquem também o intelectual.(PARANÁ, 1910a, p. 5)

A inauguração do edifício, ainda em fase final de construção, do primeiro grupo escolar do Paraná ocorre em 1903. Antes dessa solenidade foi de fundamental importância para a implantação desse tipo de organização escolar, a visita exploratória feita pelo Diretor Geral de Instrução Pública do Paraná, Professor Victor Ferreira do Amaral, ao estado de São Paulo, a fim de conhecer maiores detalhes sobre o funcionamento e a organização dos grupos escolares daquele Estado. ${ }^{2}$

Desde os primeiros anos da República, o debate entre intelectuais, políticos e educadores paulistas fluía para um tipo de escola primária que pretendia ser moderna e diferente daquela existente no Império: carente de edifícios, mobiliários e livros didáticos, precário em pessoal docente qualificado para o ensino de crianças e distante dos modernos métodos pedagógicos. Nesse sentido, para a recém instalada república brasileira, a experiência inovadora das escolas primárias graduadas - ou grupos escolares, como vieram a ser denominadas - foi entendida como um investimento que contribuiria para a consolidação de uma intencionalidade que procurava, por sua vez, esquecer a experiência do Império e apresentar um novo tipo de educação que pretendia ser popular e universal.

A respeito da criação dos grupos escolares no Brasil, como afirma SOUZA (1998), desde o início da República, havia intelectuais e educadores que pensavam a escola moderna com diversas salas e vários professores. Em São Paulo, destacou-se o pensamento do deputado Gabriel Prestes, manifestado, em 1892, por ocasião dos debates em torno do projeto de lei da reforma da instrução pública daquele Estado, que ao apontar a situação precária de suas escolas (sem casa, sem mobília, sem aparelhos de ensino etc),

\footnotetext{
${ }^{2}$ No mesmo período, o Inspetor Técnico do Ensino de Minas Gerais, Estevam Oliveira, foi enviado em 1902, pelo governo mineiro a fim de conhecer a experiência dos grupos escolares paulistas. (Cf. FARIA FILHO, L. M. de. Dos Pardieiros aos Palácios. Cultura Escolar e Urbana em Belo Horizonte na Primeira República. Passo Fundo: Editora da UPF, 2000, p. 27).
} 
defendeu a criação paulatina de novos tipos de escolas primárias como meio de evitar a ruína da República. Dessa forma, apoiando-se nas experiências americana e européia, Gabriel Prestes argumentava que a implantação da escola graduada era conveniente para os cofres do Estado por possuir qualidades pedagógicas e benefícios econômicos, tais como a melhor divisão do trabalho do professor e o aumento da oferta da instrução popular que atendesse a um maior número de crianças. Portanto, conclui a autora, "as representações sobre a escola graduada buscavam articular o ideal da renovação do ensino com o projeto político de disseminação da educação popular aliado às vantagens econômicas." (SOUZA, 1998, p. 44)

Essa modalidade de escola, continua SOUZA (1999, p. 104), implantada pela primeira vez no Brasil no ano de 1893, em São Paulo, correspondeu, na época, a um novo modelo de organização administrativo-pedagógico da escola primária com base na graduação escolar. Segundo os estudos VIÑAO (1990) sobre a escola graduada, este tipo de organização implicava uma determinada ordenação do espaço, das atividades, dos ritmos e dos tempos, assim como uma distribuição de usos desses espaços e objetos, e uma classificação-valorização de professores e alunos, ou seja, não se tratava apenas de uma divisão horizontal e vertical do trabalho, senão, sobretudo, uma cultura ou modo de vida específico. (VIÑAO, 1990, p. 7)

Todavia, complementa FARIA FILHO (2000, p.37), os grupos escolares e seu processo de organização significavam não apenas um novo modo de ordenar e educar, mas, necessariamente, uma estratégia de ação na esfera educativa escolar, moldando práticas, legitimando competências e propondo metodologias do ensino através da produção e divulgação de novas representações escolares.

Impelido por esta visão é que o Diretor Geral de Instrução Pública retornou a Curitiba e tentou estabelecer padrões que procurassem se assemelhar àqueles encontrados em São Paulo.

Entretanto, é preciso esclarecer que a consolidação desta experiência de organização não se efetivou imediatamente em Curitiba. Foram necessários maiores esforços para modificar a realidade escolar, a fim de aproximá-la do discurso dos poderes públicos. Assim, após uma década da inauguração, em 1903, do edifício Grupo Escolar Dr. Xavier da Silva - criado para servir de modelo à organização de outros grupos que, mais tarde, o governo fundaria na capital e em outras cidades do Paraná (PARANÁ, 1905, p. 51) - , permaneciam as mesmas reivindicações das autoridades de ensino que insistiam na reorganização das escolas públicas primárias. Dessa forma, tal preocupação pôde ser percebida na declaração feita pelo Diretor Geral da Instrução Pública, Francisco Ribeiro de Azevedo Macedo, quando colocou em execução de modo mais sistemático a escola graduada paranaense, dividindo o trabalho por séries entre os respectivos professores, e confiando a um desses a função de diretor.

[...] formei, assim, o que em falta de melhor denominação, chamamos de grupos ou semigrupos escolares. Sem dúvida, esses estabelecimentos não são organizados à feição dos afamados grupos escolares paulistas, compostos de uma secção para os meninos e outra para meninas, dispondo de todo o 
material técnico para o ensino e tendo pessoal administrativo diferente do pessoal docente. (PARANÁ, 1915, p. 03)

Diante das dificuldades de implantação da nova organização escolar e reconhecendo o adiantamento da instrução pública no estado de São Paulo, o governo paranaense decidiu enviar, em 1916, uma comissão de professores normalistas para estudar, durante meses, o funcionamento dos grupos escolares paulistas.

As atividades desenvolvidas pela comissão foram resumidas num ofício do Diretor Geral da Instrução Pública de São Paulo, João Chrisóstomo B. R. Júnior, encaminhado ao Secretário de Negócios do Interior, Justiça e Instrução Pública do Estado do Paraná, Enéas Marques dos Santos:

Deixa hoje este Estado a comissão de professores paranaenses, que aqui permaneceu durante algum tempo em estudos em nossas escolas, sob a chefia do snr. Professor Trajano Sigwalt. É-me sumamente grato comunicar a V. Exa. que os distintos moços a quem V. Exa. confiou a delicada missão de estudar a organização do ensino primário neste Estado desempenharam-se galhardamente da honrosa incumbência, frequentando com o máximo desvelado interesses os estabelecimentos de ensino que lhes foram designados. (PARANÁ, 1916, p. 4-5).

$\mathrm{Na}$ década anterior, Reinaldo Machado, Diretor Geral Interino da Instrução Pública do Estado do Paraná, , alertava que os grupos escolares não deveriam ser a mera reunião de escolas em um edifício, mas uma sequiência metódica e sistemática do ensino, sendo necessário, portanto, submetê-los a uma regulamentação científica. Desse modo, enfatizava que a criança, na medida do seu aproveitamento, passaria por diversas classes e graus, cada vez mais aperfeiçoando sua educação intelectual, física e moral, que lhe era fornecida gratuitamente pelo Estado. Dessa maneira, discursava Reinaldo Machado, ao sair do grupo, o aluno estaria "armado para a luta pela vida e apto para ser um cidadão útil ao Paraná e à República”. (PARANÁ, 1905, p. 51)

Esta idéia - preparar crianças para se tornarem futuros cidadãos capazes para o mundo moderno - foi continuamente utilizada nos argumentos discursivos que apresentavam a instrução pública como co-responsável nessa missão e é o que se nota na fala de Vicente Machado, Presidente do Estado, dirigida aos deputados paranaenses em 1907: “[...] Já não significa esta preocupação uma simples predileção de meu espírito, mas sim a convicção arraigada de que à solidez e propagação do ensino estão ligados o progresso e a força dos modernos povos". (PARANÁ, 1907b, p. 6)

Outro exemplo dessa retórica aparece em 1929 e pertence ao Presidente do Estado, Affonso Alves de Camargo: "[...] No meu discurso-plataforma disse que: prosseguia na nobre tarefa de difundir ainda mais a instrução, pois é bom que o administrador veja em cada escola um templo onde se cultua a família e a Pátria e onde se pode fazer de cada brasileiro um cidadão consciente de seus deveres cívicos e um real valor para a nacionalidade". (PANANÁ, 1929, p. 128) 
Não restam dúvidas de que o investimento dos poderes públicos paranaenses não correspondeu às expectativas de um discurso que propunha a regeneração da sociedade por meio da educação. Ainda que houvesse um distanciamento entre a retórica do Estado e a aplicação de recursos na área educacional, o debate de intelectuais, educadores e políticos paranaenses que propunham novos formatos, concepções e métodos para uma escola que pretendia ser moderna, colaborou na construção de resultados que tiveram ressonâncias nos grupos escolares mantidos pelo Estado.

Apesar de não terem sido os resultados que os interlocutores dos debates educacionais esperavam, não se pode reduzir, com este entendimento, as práticas que construíram aquela realidade histórica à racionalidade que organizou os discursos. E, nesse sentido, é oportuna a colocação de CHARTIER (1997), ao postular que a lógica que conduz as operações que constituem as instituições, dominações e relações não possui a mesma estrutura lógica hermenêutica, logocêntrica e escritural que produz os discursos, não podendo, portanto, a eles ser reduzida CHARTIER (1997).

\section{Arquitetura e Espaço Escolar em Curitiba}

De forma constante nuestro ser queda encuadrado em el espacio.A través del volumen espacial nos movemos, vemos las formas y los objetos, oímos los sonidos, sentimos el viento, olemos la fragancia de un jardín en flor. En sí mismo carece de forma. Su forma visual, su cualidad luminosa, sus dimensiones y su escola derivan por completo de sus limites, en quanto están definidos por elementos formales. Cuando un espacio comienza a ser aprehendido,encerrado, conformado y estruturado por elementos de la forma, la arquitetura empieza a existir.

Francis D.K.CHING (1996, p. 92)

Um edifício próprio para a escola: eis uma importante questão que os poderes públicos tiveram que enfrentar diante do comprometimento discursivo que coroava a instrução escolar como uma das principais colunas de sustentação da civilização. Assim, do mesmo modo que para ser professor era necessário alguém qualificado, esclarece VIÑAO (1993-4, p.25), também se tornou indispensável um espaço e um edifício próprios, especificamente selecionados e concebidos para ser uma escola. "Nesse sentido,o espaço escolar seria um lugar que deveria ser demarcado como tal e a fragmentar-se internamente em uma variedade de usos e funções de natureza produtiva,simbólica e disciplinadora." (VIÑAO, 1998, p.97)

Portanto, para os poderes públicos, tornou-se imperativo empregar recursos na construção dos edifícios escolares convenientes à sua função. Entretanto, este investimento, que contribuiu para o enaltecimento da República, tornou-se muito mais 
uma estratégia de visibilidade do que uma ação que necessariamente democratizaria a escola.

Apesar de possuírem um programa arquitetônico que os identificava enquanto espaços públicos de escolarização, a introdução desse tipo de edifício público na cena curitibana seguiu, parcialmente, as regras de construção ancoradas nas normas e preceitos da moderna pedagogia, ficando a organização do espaço de alguns desses edifícios incoerentes à propaganda do governo de que destinaria um lugar diferenciado para a formação de bons cidadãos à Pátria.

Tome-se como exemplo o Grupo Escolar Dr. Xavier da Silva.

Francisco Xavier da Silva no último ano de seu terceiro mandato como governador do Estado, em 1903, resolveu inserir nas comemorações do Cinqüentenário de Emancipação Política do Paraná, a construção de um grande edifício escolar que estivesse sintonizado com a importância daquela data. No relatório do Secretário de Estado dos Negócios e Obras Públicas e Colonização, Arthur Pedreira de Cerqueira, de 31 de dezembro de 1903, apresentado ao governador Xavier da Silva, nos fornece informações do andamento do projeto.

Tendo o governo adquirido por compra o terreno contíguo ao prédio $\mathrm{n}^{\circ}$. 40 da Rua Marechal Floriano Peixoto, com 74 metros de frente para esta rua e 86,70 para a Rua Silva Jardim, mandou-se nele construir um grupo escolar que será denominado Xavier da Silva, contendo seis escolas, três para cada sexo. Os trabalhos deste edifício que conto ficar concluído dentro do governo de V. Ex., estão bastante adiantados. (PARANÁ, 1904a, p. 17) ${ }^{3}$

Mesmo não conseguindo cumprir o cronograma, o prédio em fase final de construção foi inaugurado na data cívica de 19 de dezembro de 1903. ${ }^{4}$ Assim, com poucos meses da entrega do cargo ao seu sucessor, este se tornaria o edifício que abrigaria o primeiro grupo escolar do Estado do Paraná, que não por mero acaso recebeu o nome de Dr. Xavier da Silva.

As fontes que afirmam que o prédio foi inaugurado no ano de 1903 não se contrapõem às informações de outras que confirmam sua entrega à comunidade em 1904, já na gestão de Vicente Machado. Contudo, esta questão não chega a constituir um debate, visto ter sido o ano de inauguração do edifício, compreendido pelas autoridades de ensino da época, como o "embrião" desta nova modalidade de ensino primário a ser implantado anos mais tarde no Estado do Paraná. Assim, desde o início, o ano de 1903 foi

\footnotetext{
${ }^{3}$ É preciso esclarecer o leitor que na grande maioria dos casos, os relatórios e mensagens do governo que relatam seus feitos e projetos eram apresentados no final de cada ano. Entretanto, a publicação na forma impressa ocorria somente no início do ano subseqüente. Assim, é preciso atentar que a data de publicação de uma fonte desta natureza não corresponde à realidade do ano de publicação, mas ao anterior, o que pode ser comprovado no próprio título do documento.

${ }^{4}$ Dia em que se comemora a emancipação do Estado do Paraná da Província de São Paulo, ocorrida no ano de 1853.
} 
incorporado como a data oficial de suas celebrações de cinqüenta anos de existência, em 1953, assim como no seu jubileu de diamantes, em 1978 (ESCOLA,1978), e na comemoração de seu centenário, em $2003 .^{5}$

Desconsiderando o fato de ter sido construído no cruzamento das Ruas Marechal Floriano Peixoto com Silva Jardim - homenagens da cidade a dois controvertidos personagens da República -, e observando o contexto urbano da época, conclui-se que o local ainda não possuía as qualidades necessárias para congregar uma escola daquele porte em tal espaço, apesar de sua arquitetura monumental e da saudável companhia de seus vizinhos. A região não era considerada apropriada, ainda que a construção estivesse ao lado de prédios destinados à administração pública, onde funcionavam as Secretarias de Obras Públicas e Colonização, do Interior e da Justiça, do Superior Tribunal de Justiça, o Fórum, a Repartição Central de Polícia, a Junta Comercial, e a Diretoria de Higiene. (PARANÁ, 1904a, p. 17).

Algumas das primeiras críticas a esse grupo escolar se deu exatamente na questão de sua localização, como a que fez o Diretor Geral Interino da Instrução Pública, Reinaldo Machado no Relatório de 1904: “[...] para aproveitar o edifício do Grupo Escolar Xavier da Silva, ultimamente construído, embora o local não seja o mais apropriado, é esta diretoria de opinião que se deve instalar o primeiro grupo escolar do Estado.” (PARANÁ, 1905, p. 51)

Esta censura será repetida pelo próximo diretor, Arthur Pedreira de Cerqueira, que explicitou melhor o incômodo causado pela localização: “[...] O Grupo Xavier da Silva não satisfaz os fins a que foi destinado por estar situado distante do centro, na extrema meridional da cidade, onde se nota pequena densidade de população escolar." (PARANÁ, 1907a, p. 20)

A imagem que se segue, do início do século XX, mostra que é possível entender a repreensão de Arthur Pedreira sobre o distanciamento do centro urbano de Curitiba e, principalmente, a baixa concentração de habitações, condições que não justificavam ter sido aquele local entendido como o mais adequado para a edificação do primeiro grupo escolar do Estado.

\footnotetext{
${ }^{5}$ No documento "Projeto 100 anos Xavier", a justificativa apresentada pelo Colégio Estadual Dr. Xavier da Silva para as comemorações do centenário é a que se segue: No ano de 2003, o Colégio Estadual Dr. Xavier da Silva completa 100 anos de existência. Por esse motivo, a direção, corpo docente e funcionários desenvolverão, ao longo deste ano, projetos e atividades que visam estimular o aluno a resgatar a história do Colégio, com o objetivo de levá-los a valorizar o presente pelo conhecimento do passado. Acreditamos ser de fundamental importância promover esta pesquisa, que nos ajudará a entender mais profundamente o caminho percorrido por aqueles que nos antecederam. (PROJETO, 2003, p. 1). Na ocasião, o Jornal Gazeta do Povo, em matéria alusiva ao evento, reforça ainda mais na memória do povo curitibano que o ano de inauguração do prédio, em 1903, é aquele que deu início a história centenária daquela instituição. (GAZETA DO POVO, 6 de junho de 2003). Ademais, a comunidade do Colégio Estadual Dr. Xavier da Silva, na noite de 26 de agosto de 2003, abriu solenemente as comemorações do centenário com a presença de ex-professores, ex-alunos e do Secretário de Educação, Maurício Requião de Mello e Silva, que inaugurou a Feira Interdisciplinar Cem Anos. (CONVITE, 2003)
} 


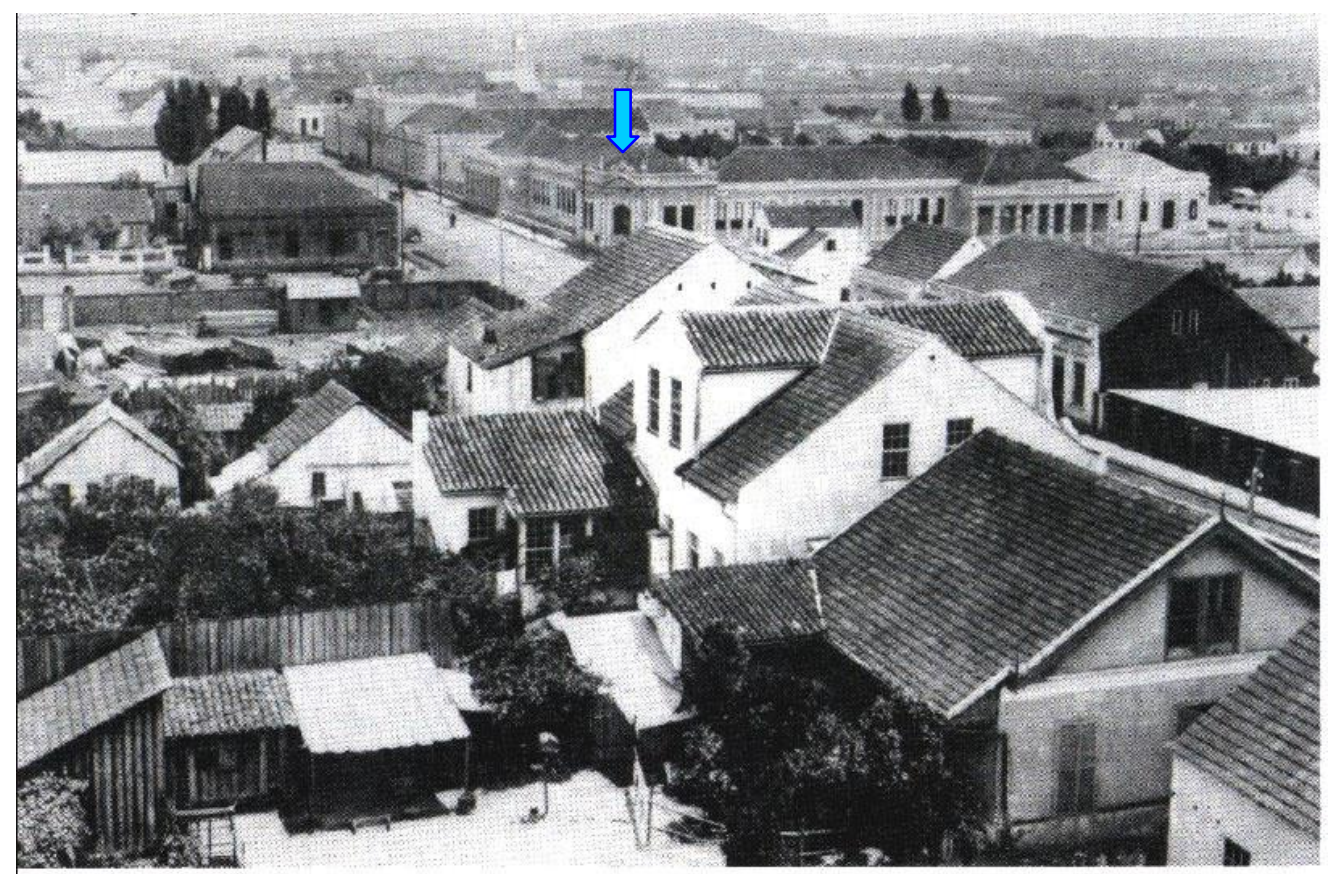

FIGURA 1 - GRUPO ESCOLAR DR. XAVIER DA SILVA - CANTO SUPERIOR CENTRAL

FONTE: Fundo Casa da Memória

Analisando o caso espanhol, sobretudo após a publicação do manual Instrucción técnico-higiénica relativa a la construcción de escuelas, de1905, VIÑAO (1993-4) apresenta dois critérios básicos que deveriam ser observados na escolha do local para a construção de edifícios escolares: a moral e a higiene.

Em primeiro lugar, a higiene: um local elevado, seco, bem arejado e com sol constitui o ideal. O que se deve evitar são, pois, os lugares úmidos, sombrios e não arejados (terrenos pantanosos e ruas estreitas). Porém a higiene é tanto física quanto moral. A relação dos lugares de proximidade perniciosa constitui, por isso, todo um repertório onde se mesclam moralidade e saúde: tabernas, cemitérios, hospitais, quartéis, depósitos de esterco, casa de espetáculos, latrinários, prisões etc. (VIÑAO, 1993-4, p.30)

A escola, em certo sentido, foi pensada para ser um espaço laboratorial, disciplinarizador difusor de práticas higiênicas e também moralizantes, afirma MARQUES (1994), em seu trabalho sobre o discurso médico-pedagógico acerca da eugenia, na década de 1920, na cidade de São Paulo. Essa visão de escola modeladora, continua MARQUES, "não só aperfeiçoava o espírito, como também conformava o corpo, fazia ver como indispensável a presença de novos saberes a compor o universo da escola.” (MARQUES, 1994, p. 101). Portanto, esses profissionais da educação 
BENCOSTTA, M. L. A. Arquitetura e espaço escolar: reflexões ...

orientaram os poderes públicos a pensar segundo uma ótica de disciplinarização da educação que contribuiria na organização do próprio espaço escolar.

Em Curitiba, a questão da higiene geral dos edifícios escolares não passou desapercebida pela imprensa local, pois, baseada nos pressupostos de uma pedagogia compreendida como moderna, enfatizava a importância do ar puro, da luz abundante e de uma adequada localização sanitária, requisitos indispensáveis para o bom estado dos grupos escolares.

A escola com relação a todas as crianças que a freqüentarem deve ser: bem localizada, para maior seguridade da frequência; isolada, para evitar tudo quanto distraia a atenção dos alunos; acessível a todos os ventos; exposta ao nascente, clara, ajardinada, mobiliada de conformidade com a estrutura do estudante e com as necessidades do ensino. (A REPÚBLICA, 1904).

Em 1929, quando foi publicado o Regulamento da Diretoria Geral de Saúde Pública do Estado do Paraná, é notório o encadeamento de proposições que reproduzem a tônica de um discurso da engenharia médico-pedagógica, que procurava determinar a maneira mais adequada de se construir edifícios públicos para fins escolares. ${ }^{6}$

No artigo 855 do Regulamento, as escolas, para poderem funcionar em prédios cujas condições fossem julgadas satisfatórias, deveriam submeter-se a uma série de determinações. A seguir citamos algumas delas:

a) Os prédios escolares, sempre que for possível, deverão ser construídos em um só pavimento, com porão de um metro de altura, no mínimo, convenientemente ventilado;

b) As dimensões das salas de classes serão proporcionais ao número de alunos, o qual não deverá exceder de $40 \mathrm{em}$ cada sala, devendo ser reservado a cada escolar uma área, no mínimo de um metro quadrado de superfície, quando as cadeiras forem duplas, 1.m235, quando individuais; c) O pé direito mínimo das salas de classe será de três metros, devendo ser aumentado, quando as condições de iluminação natural assim o exigirem;

e) As salas de classe terão preferentemente a forma retangular, cujos lados guardem a relação de 2 para 3 ;

h) A iluminação das classes deverá ser unilateral esquerda, sendo tolerada a bilateral, desde que proceda de faces paralelas;

j) A iluminação das classes deverá ser tal, que na fila de carteiras mais afastadas das janelas o centro da mesa receba iluminação em dias nublados, nunca inferior a vinte e cinco luzes;

${ }^{6}$ O Decreto n. ${ }^{\circ} 2.141$, de 14 de novembro de 1911, já tratava desta questão em seu capítulo VI. (Cf. MARQUES, V. R. B. A medicalização da raça: médicos, educadores e discurso eugênico. Campinas: Editora da Unicamp, 1994. p. 162 - 163). 
1) A ventilação das salas deverá ser perfeita, sem correntes de ar que possam prejudicar as saúde das crianças;

m) Disporão de latrinas na proporção mínima de uma para trinta alunos freqüentes, do sexo masculino, e de uma para cada grupo de vinte alunos, do sexo feminino.

p) O interior das escolas, sempre que for possível, deverá ser revestido de material que permita lavagens freqüentes sem se deteriorar, com tonalidades suaves, como por exemplo, cinzento - claro, azulado ou esverdeado, sem saliências nem reintrancias;

q) Os prédios escolares deverão dispor de amplo campo destinado ao recreio e exercícios físicos, devendo uma parte deste ser coberta de material mau condutor de calor. (REGULAMENTO, 1929, p. 132 - 133).

Essas determinações - de um espaço funcional e simbólico - presentes na legislação paranaense e nacional, já não eram nenhuma novidade na Europa, principalmente na França da III República, que, desde 1868, por ação de Jules Ferry, determinava não ser mais admissível uma sala de aula de uma instituição pública sem material, mobiliário e um agenciamento do espaço completamente específico. Dentre outras especificações, Ferry regulamentou, desde 1882, que a sala de aula deveria ter uma forma retangular, o piso de paquet de madeira resistente, uma altura do teto de aproximadamente quatro metros, oferecer uma superfície mínima de $1,25 \mathrm{~m}^{2}$ por aluno e não exceder a cinquienta lugares. As escrivaninhas deveriam ser de quatro ou seis lugares em substituição às de dois, por serem menos propícias aos contágios e mais facilmente adaptáveis ao tamanho do aluno, além de facilitar a circulação do professor. (GAULUPEAU; ROZINOEN; LAMINAUD, 2001, p. 14 - 15).

Tendo como referência a foto de sua fachada, pode-se dizer que o edifício do Grupo Escolar Dr. Xavier da Silva (figura 2) trata-se de um exemplo de programa arquitetônico escolar projetado de forma monumental. Disposto em um eixo longitudinal paralelo às ruas Marechal Floriano Peixoto e Silva Jardim, sua fachada é ornamentada por um conjunto de elementos decorativos semineoclássicos (eclético), contendo, em destaque, um medalhão com o ano de sua inauguração (1903) incrustado em alto relevo na parte superior do frontão. O resultado harmonioso é decorrente, principalmente, de sua simetria volumétrica e sua unidade de tratamento formal. Apresenta, ainda, uma adequada relação entre construção e terreno, o que faz esse edifício, juntamente com os seus vizinhos da Marechal Floriano, sobressair-se a ponto de registrar sua imagem, que consolidou-se ao longo das transformações da cidade na memória dos curitibanos.

Considerando as colocações de ZEVI (2000), a fotografia de fachada de prédios não possui a função de transmitir a essência espacial do edifício, entretanto, ela cumpre a importante missão de reproduzir tudo aquilo que, no olhar do fotógrafo, foi possível enquadrar da natureza bidimensional e tridimensional da edificação. Evidentemente, por 
maior que seja a série de imagens sobre uma construção arquitetônica, não é possível esgotar suas dimensões simbólicas. ${ }^{7}$ Assim:

Cada fotografia engloba o edifício de um único ponto de vista, estaticamente, de uma maneira que exclui esse processo, que poderíamos chamar musical, de contínuas sucessões de pontos de vista que o observador vive no seu movimento dentro e ao redor do edifício. Cada fotografia é uma frase separada de um poema sinfônico ou de um discurso poético, cujo valor essencial é o valor sintético do conjunto. (ZEVI, 2000, p. 50).

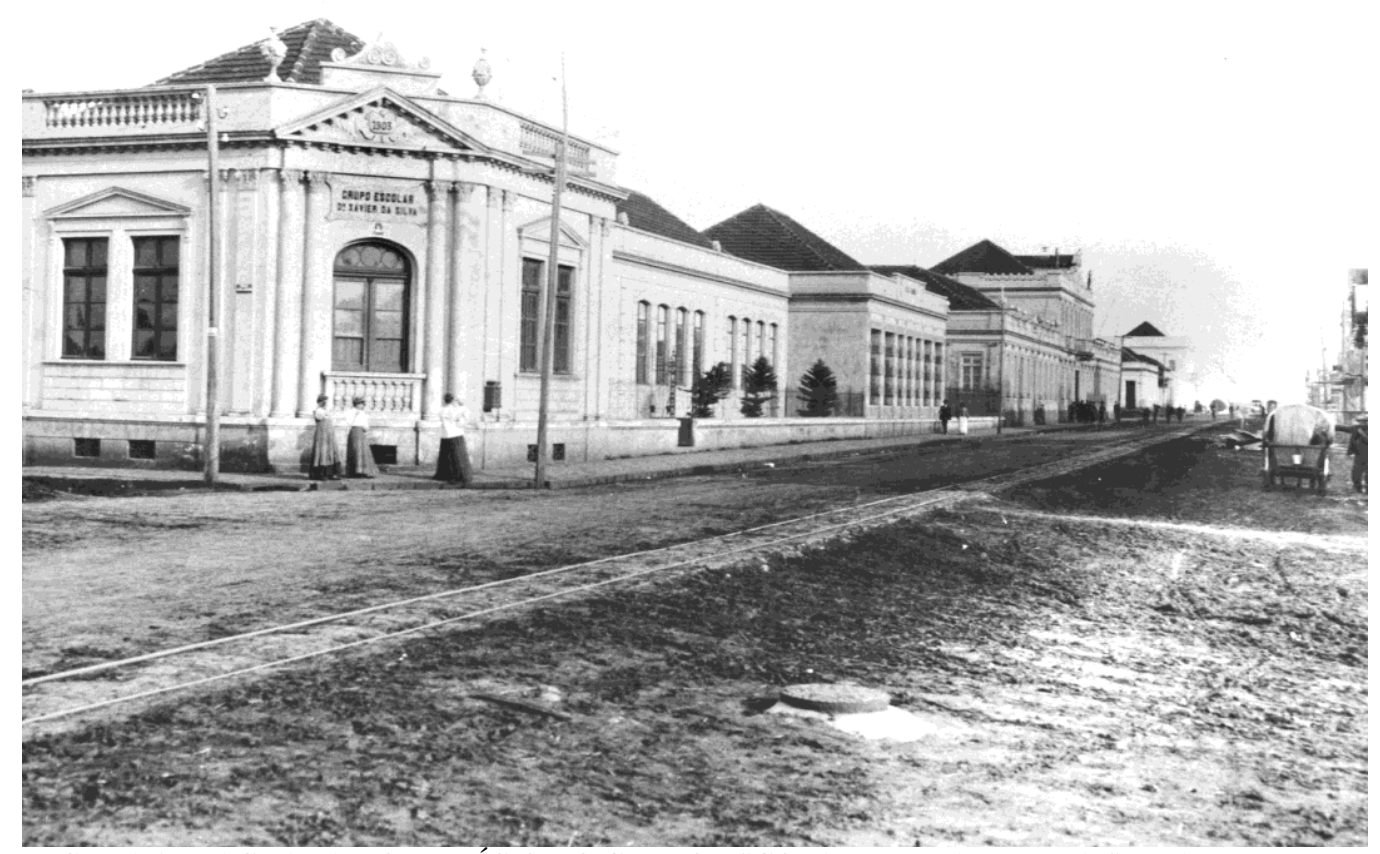

FIGURA 2 - FACHADA DO EDIFICIO DO GRUPO ESCOLAR DR. XAVIER DA SILVA

FONTE: Fundo Casa da Memória

A planta baixa (figura 3), organizada por Cândido de Abreu (RELATORIO, 1904 , p. 8), que será analisada a seguir, diferente da fotografia de fachada, é uma potencial fonte através da qual se pode examinar a estrutura de uma obra arquitetônica.

${ }^{7}$ Sobre a questão dos significados e representações do espaço escolar como objeto de pesquisa histórica consultar VIÑAO (1998). 


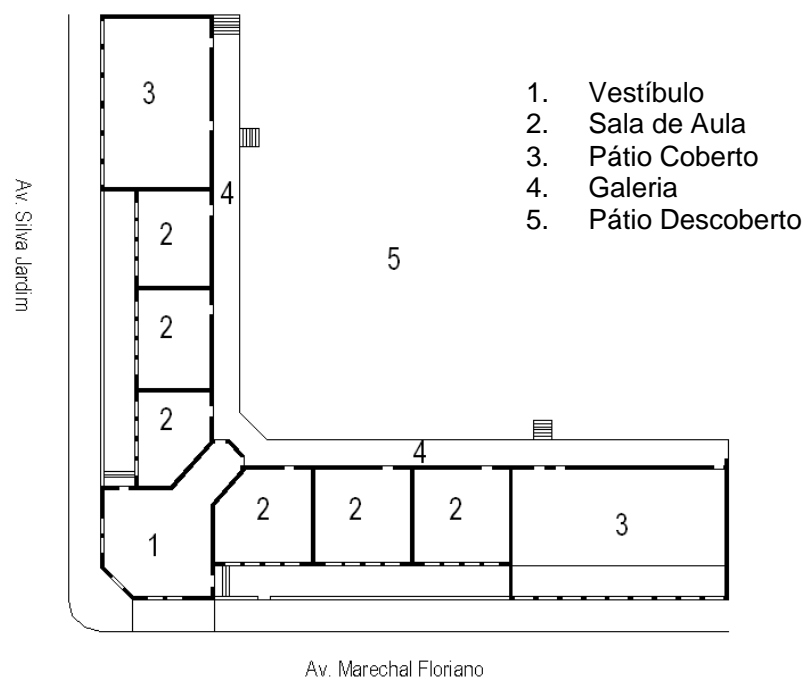

FIGURA 3 - PLANTA BAIXA DO GRUPO ESCOLAR DR. XAVIER DA SILVA FONTE: Coordenadoria do Patrimônio - Secretaria de Administração do Paraná

Uma primeira interpretação do espaço do Grupo Escolar Dr. Xavier da Silva é de que se trata de um prédio voltado para o seu interior.

O plano arquitetônico em L indica, na sua fachada, rente à rua, a função de resguardar o pátio interno em torno do qual estão interligadas as dependências do edifício. ${ }^{8}$ Este jogo combinatório, que coloca um limite à liberdade visual e espacial do observador, é decorrente da antítese entre o espaço exterior e o interior, que tem, na sua fachada, a linha divisória que desperta a admiração daquele que a contempla ao mesmo tempo em que produz o ocultamento de seu interior. Sobre esta questão, BOUDON (1971) esclarece não poder existir interior sem exterior, e se a arquitetura é interior, necessariamente ela não pode existir enquanto arquitetura sem um exterior. Desse modo, por se tratar de um item pertencente ao espaço interno, não se pode confundir a fachada como inerente ao espaço exterior, pois este é referente à rua, à praça etc.

Um grupo escolar atraente: é uma outra interpretação a respeito do Xavier da Silva. Os poderes públicos investiram para que ele fosse alegre e empolgante, desde a contratação de seus professores até a aquisição de moderno mobiliário, quadros, mostradores etc., e sua imagem arquitetônica não deveria ser uma exceção.

[...] para que, pois, a escola seja atraente mister é que além do prédio, de sua posição topográfica, das linhas de sua compostura arquitetônica, ela se revista interiormente de tal aparato decorativo que o seu aspecto

${ }^{8}$ Entre os anos de 1932-1937 é construída uma nova ala com mais três salas de aulas que transformam a planta original em L para U. 
constitua uma fonte segura de ensinamento, não sendo esse referido aparato meramente cenográfico, estéril e improfícuo, mas inteligentemente disposto para despertar na criança a cultura do belo. (PARANÁ: 1913b, p. 8).

Mesmo a alegria deveria ser objeto de constante inspeção no controle dos usos do espaço interno do edifício-escola que, certamente, adotou regras de vigilância panópticas, já amplamente discutidas e explicadas por FOUCAULT (1983) e STAROBINSKY (1988). Basta notar na planta baixa (figura 3), do que era anteriormente o vestíbulo, depois transformado na sala do diretor (PARANÁ, 1913a, p. 106) é possível ter uma visão privilegiada do que estava ocorrendo na galeria para as salas de aula e, principalmente, no pátio descoberto. Ademais, a passagem por onde circulavam os alunos, quando de sua entrada e saída da instituição, não escapava aos olhos dos professores.

ESCOLANO (1993-4) mostrou bem como esta espacialização disciplinar compõe a arquitetura escolar ao observar, dentre outros detalhes, a divisão das salas de aula por idade e sexo e a disposição das carteiras enquanto elementos da planificação panóptica do espaço. "Tais dispositivos são, além do mais, coerentes com as teorias arquitetônicas modernas que sustentam que as pessoas e os objetos se relacionam precisamente através de sua separação no e pelo espaço." (ESCOLANO, 1993-4, p. 101).

Os grupos escolares espalhados pelo Brasil no início do século XX, em especial aqueles identificados por seu programa arquitetônico de natureza monumental, incluso entre eles o Xavier da Silva, visavam, dentre outros objetivos, já apontados por VIDAL e FARIA FILHO (2000, p. 25), "incutir nos alunos o apreço à educação racional e científica, valorizando uma simbologia estética, cultural e ideológica construída pelas Luzes da República".

Para finalizar estas rápidas reflexões a respeito do Xavier da Silva, é importante ressaltar que o investimento dos poderes públicos em querer torná-lo um modelo para os demais grupos escolares do Estado, como de fato veio a ser oficializado (PANANÁ, 1917 a, p. 8) ${ }^{9}$, não o isentou de censuras. O edifício foi criticado pela escolha de sua localização, como já foi dito anteriormente, mas também pela organização de seu espaço interno. A distribuição inadequada da luz no interior de suas salas de aula, por exemplo,

\footnotetext{
${ }^{9}$ Trecho do Relatório do Inspetor Escolar da Capital, Cândido Natividade da Silva, encaminhado ao Secretário dos Negócios do Interior, Justiça e Instrução Pública: “O grupo modelo, em boa hora instituído nesta capital e sob a competente direção do professor Trajano Sigwalt, compreendendo escolhido corpo docente, está prestando à Instrução Pública, apesar do pouco tempo de funcionamento, muito bons serviços. Funciona o grupo modelo com duas secções: masculina e feminina, compreendendo cada secção quatro professores (quatro anos), muitos alunos e professores substitutos. O número de alunos matriculados é de 335 (matrícula útil), sendo a matrícula máxima de 407 alunos de ambos os sexos, obedecendo aos trabalhos escolares o seguinte horário: - de 12 às 16:30, com intervalo de 20 minutos para descanso dos alunos e professores (14:25 às 14:45), para o $2^{\circ} .^{\circ} 3 .^{\circ}$ e $4 .^{\circ}$ ano, em ambas as secções; para o $1 .^{\circ}$ ano, há ainda um intervalo de 10 minutos em cada secção. Consignando aqui a excelente impressão que recebi, visitando o grupo modelo, deixo de minuciar a visita." (PARANÁ, 1917a, p. 176).
} 
BENCOSTTA, M. L. A. Arquitetura e espaço escolar: reflexões ...

foi severamente condenada por Jayme Dormund dos Reis, Diretor Geral Interino da Instrução Pública, em Relatório publicado em 1910.

[...] sem querer minuciosamente apontar os defeitos havidos na observância de tais preceitos, um único aqui exaro para apoiar minha asserção, e esse é o que se refere à distribuição defeituosa da luz, no Grupo Xavier da Silva, causa de futuras lesões oculares, não só nos alunos, como também nos professores, se não forem adotadas, com presteza medidas de correção. (PARANÁ: 1910a, p. 4).

Se quem é rei nunca perde a majestade, segundo o dito popular, o edifício-escola do Xavier da Silva conseguiu manter sua coroa durante os primeiros anos da implantação desta nova forma de organizar o ensino primário que foi o grupo escolar. O governo, seu mantenedor, procurava demonstrar que o esforço em investir em algumas unidades de seu sistema de ensino poderia surtir representações que significassem que ele estaria cumprindo a premissa de educação popular para todos. A análise e reflexão dos demais grupos escolares curitibanos nos remete a uma outra significação.

Até 1903, portanto antes da inauguração do Grupo Escolar Dr. Xavier da Silva, funcionavam, em Curitiba, três escolas púbicas de ensino primário - para o atendimento do sexo feminino, a Escola Tiradentes e Escola Carvalho, e para o sexo masculino, a Escola Oliveira Bello (PARANÁ, 1904b, p. 7). Posteriormente, as três seriam transformadas em escolas graduadas. Nessa fase de implantação, foram ainda instituídos na cidade mais oito grupos escolares além dos três acima citados. São eles: Cruz Machado, Conselheiro Zacarias, Presidente Pedrosa, Professor Brandão, Professor Cleto, Rio Branco, 19 de Dezembro e Pedro II.

A contrapartida do Estado, até então, não conseguia resolver a demanda de ensino que os filhos da cidade reivindicavam às autoridades de ensino, o que será reconhecido pelo próprio Presidente do Estado, Affonso Alves de Camargo, em 1920:

Ainda para atender ao vultuoso número de crianças em idade escolar, nesta capital, não será demasiado dizer que os grupos existentes não mais comportam as crianças que o procuram, motivo porque há necessidade de serem construídos mais três estabelecimentos de ensino, com capacidade de 800 alunos, cada um. (PARANÁ, 1920, p. 19).

Se para estas autoridades era um fato incontestável que a grandeza e a prosperidade da sociedade curitibana estava na razão direta do grau de instrução e civilização que a acompanhava, deveria ser um princípio básico de sua organização social a cultura intelectual, que o cidadão, desde criança, adquiriria aos poucos a partir de sua entrada na escola primária (PARANÁ, 1908, p. 58); seria, pois, de se esperar que a principal autoridade do estado do Paraná fosse a primeira a reconhecer a incoerência de se aguardar o crescimento do número de crianças em idade escolar, para somente depois organizar uma oferta adequada a essa demanda. 
Entretanto, a reorganização do ensino primário caminhava paulatinamente. A divisão por séries, com programas específicos, segundo algumas normas da moderna pedagogia para a educação elementar, a reunião de escolas em grupos e semi-grupos, a divisão do trabalho dos professores etc, compunham o cenário de uma realidade que estava sendo inserida no Paraná. Em todo caso, a construção dos novos edifícios-escola na cidade e no Estado parecia satisfazer às condições de higiene, localização e espacialização. As impressões das autoridades de ensino sobre tais condições não divergem com o passar do tempo. Veja-se as opiniões de dois diretores e de um delegado do ensino em três diferentes momentos.

A primeira é do Diretor Geral de Instrução Pública, Arthur Pedreira de Cerqueira:

[...] É conveniente insistir V. Exª . no sentido de serem construídos edifícios apropriados, isto é, altos, espaçosos, claros e fartamente arejados, havendo nas paredes inscrições que concitem as crianças ao cumprimento do dever cívico.

[...] segundo a opinião mais corrente, a orientação das casas escolares deve subordinar-se ao clima da localidade, sendo sempre preferível evitar que o frontispício vise para o poente. (PARANÁ, 1907b, p. 20).

Em seguida, apresentamos as considerações de um outro Diretor, Francisco Ribeiro de Azevedo Macedo:

[...] as nossas atuais casas escolares são, em regra, de belo estilo arquitetônico, têm todas as condições de aeração e de luz, dotadas umas de quatro amplos salões, outras apenas com dois; nas de quatro salões podemos instalar as quatro séries do ensino, uma a cargo de cada professor - é o nosso grupo escolar; nas de dois salões deixamos cada professor. (PARANÁ, 1915a, p. 3).

E, por fim, será reproduzida aqui a opinião do Delegado de Ensino e Inspetor Escolar Interino de Curitiba, Cândido Natividade da Silva: "[...] Os grupos escolares estão todos providos de excelente mobiliário e material técnico, dispondo todos de muita luz e aeração." (PARANÁ, 1917 b, p. 175).

Os belos estilos arquitetônicos, mencionados por Francisco Ribeiro de Azevedo, dizem respeito aos edifícios destinados ao uso escolar, alguns dos quais ainda funcionavam em prédios adaptados para sua nova função, como o Tiradentes, Oliveira Bello e Carvalho.

O primeiro edifício do Grupo Escolar Tiradentes (figura 4) é o mesmo da antiga Escola Tiradentes, criada em 1892 por ocasião das comemorações do centenário da Inconfidência Mineira. Coube à Sociedade Propagadora Herva Mate a responsabilidade por sua construção, sob os cuidados de seu presidente, o Comendador Ildefonso Pereira Correia (Barão do Cerro Azul). 
Conforme Ata de Instalação, lavrada no Livro de Termos de Visita, da primeira cadeira para o sexo feminino de Curitiba, sua inauguração ocorreu em 1895, quando assumiu sua direção a professora Júlia Wanderley (HISTÓRICO, 1975, p. 2).

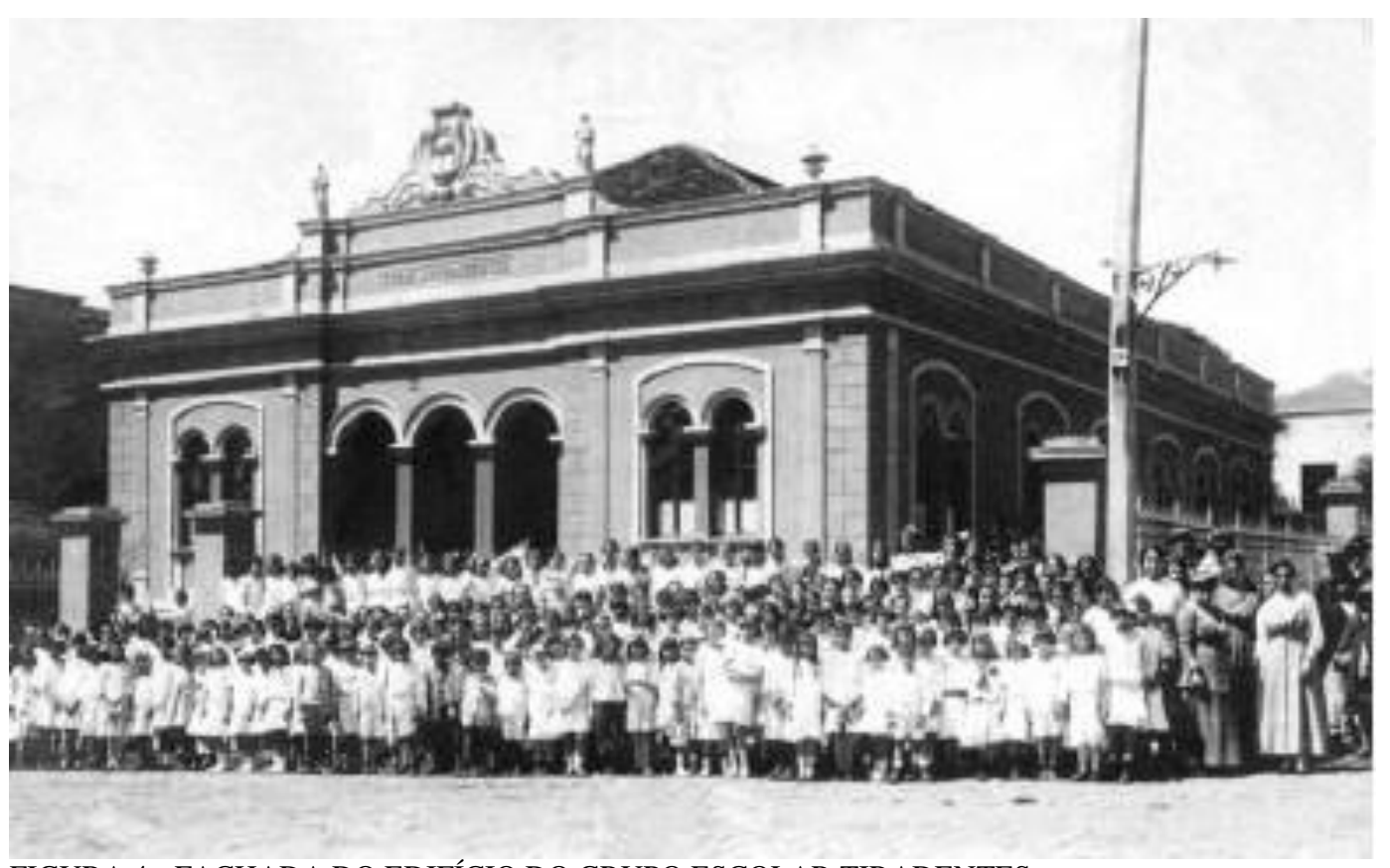

FIGURA 4 - FACHADA DO EDIFÍCIO DO GRUPO ESCOLAR TIRADENTES

FONTE: PARANÁ, 1916

Localizada na Rua Serrito (atual Professor Carlos Cavalcanti), a Escola Tiradentes foi transformada em grupo escolar em 1914, atendendo quatro séries exclusivamente para o sexo feminino. Por sua privilegiada localização, nas proximidades da Catedral e da Estação do Telégrafo de Curitiba, portanto visível pela grande maioria de transeuntes que circulavam pela área central da cidade, esse edifício não passou desapercebido, principalmente por sua fachada aprazível, caracterizada pelo movimento constante das janelas em arco pleno, interpostas por pequenas colunas.

Entretanto, apesar de sua singularidade, o edifício deste grupo escolar foi demolido em 1934 e passou um longo período de tempo funcionando em caráter provisório, instalado em residências, muitas delas inadequadas para subsistirem como escolas. Somente em 1962, o Tiradentes passa a ter um endereço definitivo, em prédio de estilo moderno, à Rua Presidente Faria, onde funciona até os dias atuais (HISTÓRICO, 1975, p. 2).

Outros edifícios construídos no século XIX para serem escolas, mas que deixaram de existir na primeira metade do século XX, foram aqueles onde funcionaram a 
Escola Oliveira Bello e a Escola Carvalho ${ }^{10}$, ambas situadas à Rua Aquidaban, atual Emiliano Perneta (PARANÁ, 1896, p. 22).

O edifício da Escola Carvalho (futuro Grupo Escolar Carvalho, figura 5) começou a ser construído em 1882, num terreno cedido pelo Comendador Antônio Martins Franco, sendo inaugurado ao final daquele mesmo ano como Escola Carvalho. No edifício também funcionou, por um longo período, a Escola de Belas Artes e Industriais do Paraná (PARANÁ, 1904a, p. 17).

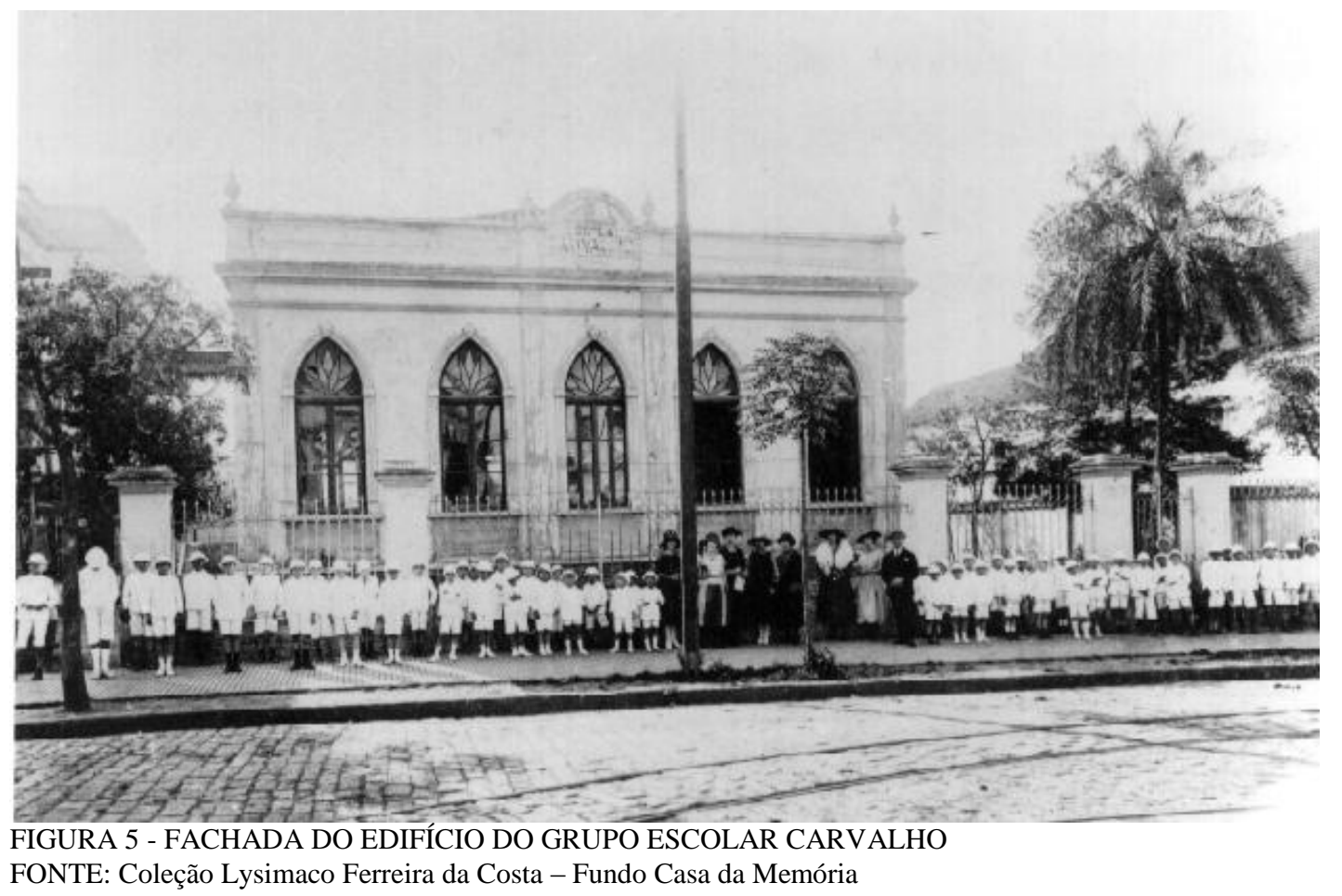

Com linhas simples e de poucos ornatos, esse edifício apresentava como principal elemento decorativo as janelas e portas em estilo neogótico, com arcos em forma de ogivas, não constituindo uma referência urbana significativa, principalmente a partir de 1922, quando, ao seu lado, foi construído o monumental edifício da Escola Normal Secundária do Paraná. ${ }^{11}$

Ainda que o edifício do Grupo Escolar Carvalho fosse espaçoso e oferecesse condições higiênicas propícias ao uso escolar, todavia era necessário, segundo Laurentino de Azambuja (Delegado Fiscal da $1^{\circ}$ Circunscrição Escolar), um espaço aberto mais

\footnotetext{
${ }^{10}$ A Escola Oliveira Bello e a Escola Carvalho aparecem na documentação de ensino como grupos escolares somente na década de 1910.

${ }^{11}$ Para maiores informações acerca das representações da arquitetura e do espaço da Escola Normal Secundária, atual Instituto de Educação do Paraná Professor Erasmo Pilotto, consultar a dissertação de Marilda Iwaya, pesquisa orientada pelo autor deste artigo.
} 
amplo para o recreio das crianças (PARANÁ, 1908, p. 63). Não se sabe se tal recomendação foi atendida, visto que em 1920 a documentação referente ao ensino de Curitiba registra a mudança do Grupo Escolar Carvalho para o prédio do Grupo Escolar Oliveira Bello, passando a existir, a partir de então, o Grupo Escolar Oliveira Bello e Carvalho ${ }^{12}$, atendendo alunos das primeiras séries de ambos os sexos.

O edifício do Grupos Escolar Carvalho passou a servir a outras necessidades do governo do Estado, que, ao final dos anos de 1920, mandou adaptá-lo para o funcionamento do anfiteatro da Escola Normal e do Jardim de Infância Maria de Miranda, que havia cedido o seu antigo prédio para a instalação da Escola Profissional Feminina (PARANÁ, 1928, p. 210). "Pavilhão construído no local da antiga Escola Carvalho, de cujo edifício foi unicamente utilizada parte das paredes externas, destina-se, também à instalação do Jardim de Infância" (PARANÁ, 1928, p.117).

O Grupo Escolar Oliveira Bello, por sua vez, estava instalado, como se pode notar na imagem a seguir (figura 6), em um nível acima, na mesma rua Aquidaban, com um pequeno recuo. A linguagem de sua fachada era assinalada por uma escadaria que ornava o frontão avançado que, apoiado em colunas circulares e encimado por um gracioso entablamento, lembrava marcadamente o estilo neoclássico.

A unidade estilística presente no Oliveira Bello não impediu, entretanto, que ele descumprisse uma das recomendações básicas para a construção de escolas: a adequada luminosidade do ambiente. Como observou, na visita que fez em 1907 ao estabelecimento, Laurentino de Azambuja, Delegado Fiscal da 1. ${ }^{a}$ Circunscrição Escolar, "a sala de aula é espaçosa, ventilada, mas não oferece os requisitos higiênicos relativos à distribuição da luz solar" (PARANÁ, 1908, p. 63). Esse problema foi certamente acentuado com o crescimento das árvores plantadas na frente do prédio, que, além de ocultar parte de sua fachada, impedia a livre penetração da luz no interior do edifício.

\footnotetext{
${ }^{12}$ Em 1920, aparece registrado nos Relatórios da Instrução Pública como Grupo Escolar Oliveira Bello e Carvalho. Em 1922, foi autorizada pelo presidente do Estado a construção de mais uma sala no mesmo Grupo. (PARANÁ, 1922, p. 87).
} 


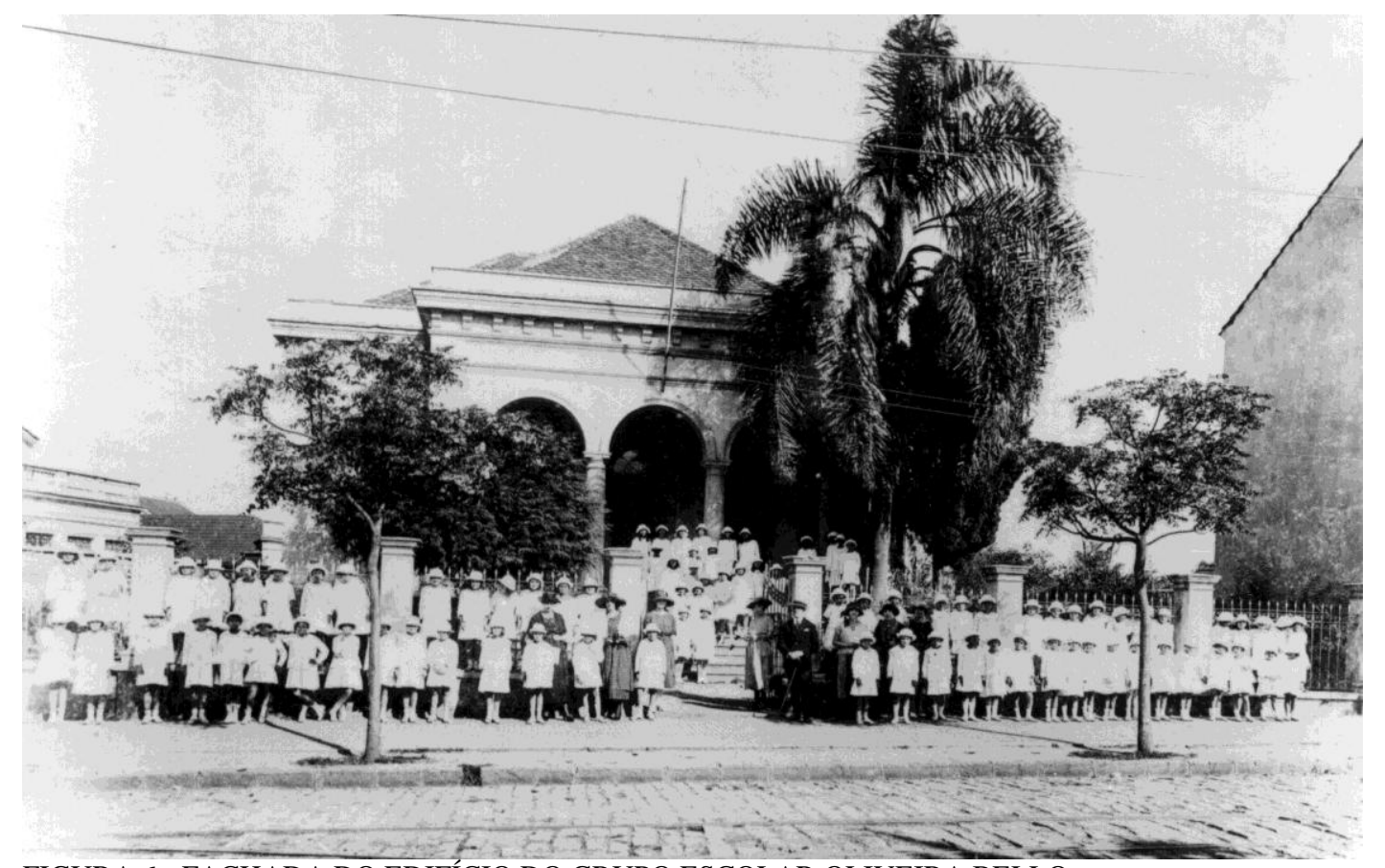

FIGURA 6 - FACHADA DO EDIFÍCIO DO GRUPO ESCOLAR OLIVEIRA BELLO

FONTE: Coleção Lysímaco Ferreira da Costa - Fundo Casa da Memória

A partir de 1925, nos relatórios dos Diretores Gerais de Ensino do Paraná, não foram encontrados registros da existência do Grupo Escolar Oliveira Bello e, muito menos, do Grupo Escolar Oliveira Bello e Carvalho, como veio a ser denominado nos seus últimos anos.

Em 1906 se daria a construção do pequeno, mas, no olhar deste historiador, o mais elegante edifício-escola da cidade de Curitiba nessa fase de organização do ensino primário. Trata-se daquele que se tornaria o Grupo Escolar Cruz Machado (figura 7), erguido no Bairro do Batel, distante alguns quilômetros do perímetro central da cidade (PARANÁ, 1907b, p. 4).

A linguagem empregada na construção do edifício do Cruz Machado, com sua fachada ricamente ornamentada com princípios decorativos da arte floral, constitui um contraponto refinado se comparado aos repertórios estilísticos adotados nos demais edifícios de grupos escolares curitibanos. Observando-se as guirlandas que encimam as janelas, percebe-se que a composição decorativa de sua fachada é pontuada por elementos superpostos vinculados ao Art-nouveau. Tais elementos contrastavam com o pórtico quadricular, sustentado por duas colunas coríntias acompanhadas por balaústres e que ocupa, neste caso, a função de proteger o acesso central do prédio. 


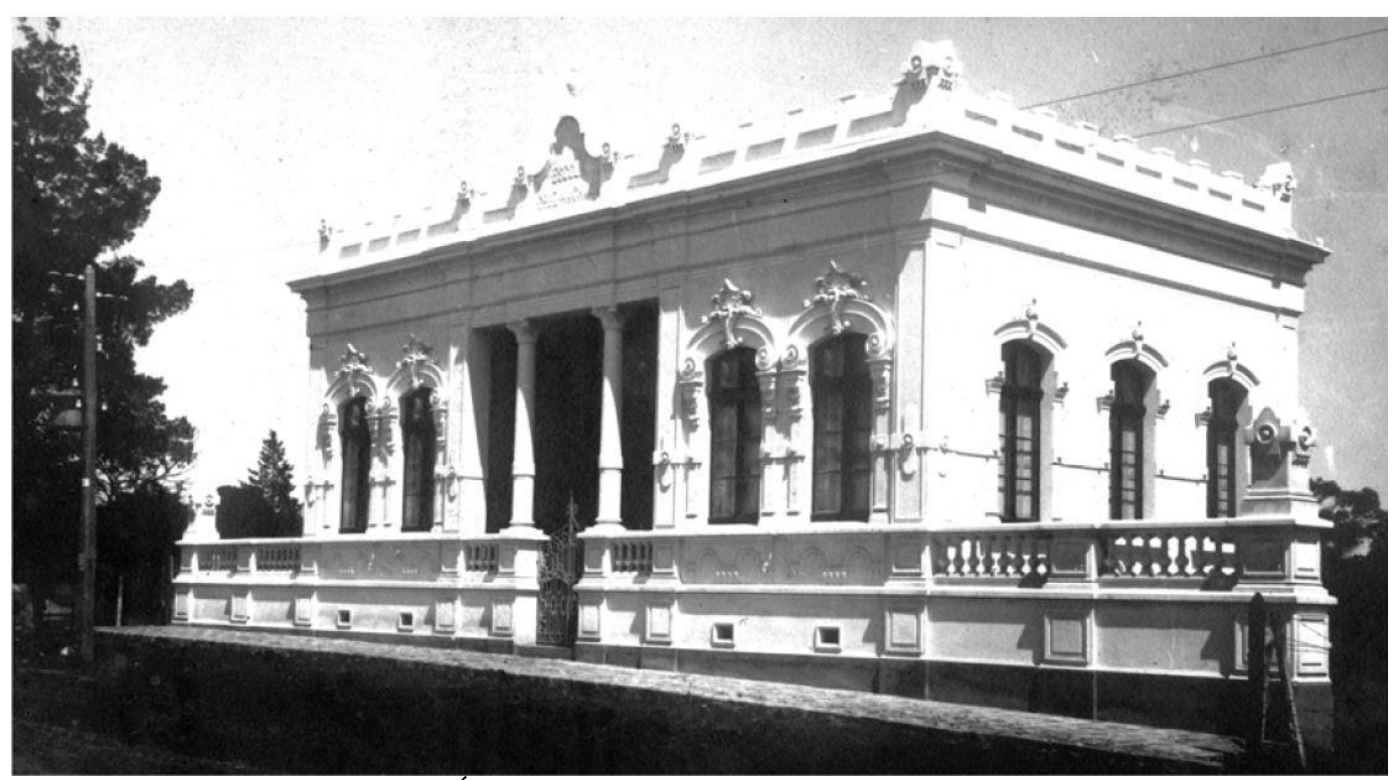

FIGURA 7 - FACHADA DO EDIFÍCIO DO GRUPO ESCOLAR CRUZ MACHADO

FONTE: Casa da Memória

Ainda que sua série de ornamentos harmoniosamente verticalizados desse ao Cruz Machado certa monumentalidade, as suas condições de funcionamento eram questionáveis, como adverte o Delegado Fiscal de Ensino, Laurentino Azambuja: "O prédio ressente-se de graves defeitos de higiene pedagógica e é insuficiente para o número de alunos que o freqüentam" (PARANÁ, 1908, p. 63). O que demonstra que nem só de fachada sobrevivia um grupo escolar.

Do mesmo modo que o Oliveira Bello e Carvalho, o Cruz Machado ${ }^{13}$ foi desativado na década de 1920, muito provavelmente em razão da inauguração, em 1928, do imponente Grupo Escolar D. Pedro II, que funcionaria quadras acima na mesma rua.

$\mathrm{Na}$ virada da década de 1910, sucedeu-se um significativo investimento em construções escolares na capital, quando foram projetados e construídos, de uma única vez, sete grupos.

Predominaram, nesse período, os projetos que continham porões altos, característica das edificações da época, que facilitavam as adaptações, em função do desnível topográfico, como meio de ventilar e proteger o piso de assoalho, como se pode perceber, por exemplo, no edifício do Grupo Escolar Professor Brandão (figura 8).

\footnotetext{
${ }^{13}$ Hoje em dia, o prédio onde funcionou o Grupo Escolar Cruz Machado, infelizmente, está sendo ocupado por uma Delegacia de Polícia Civil do Estado do Paraná.
} 


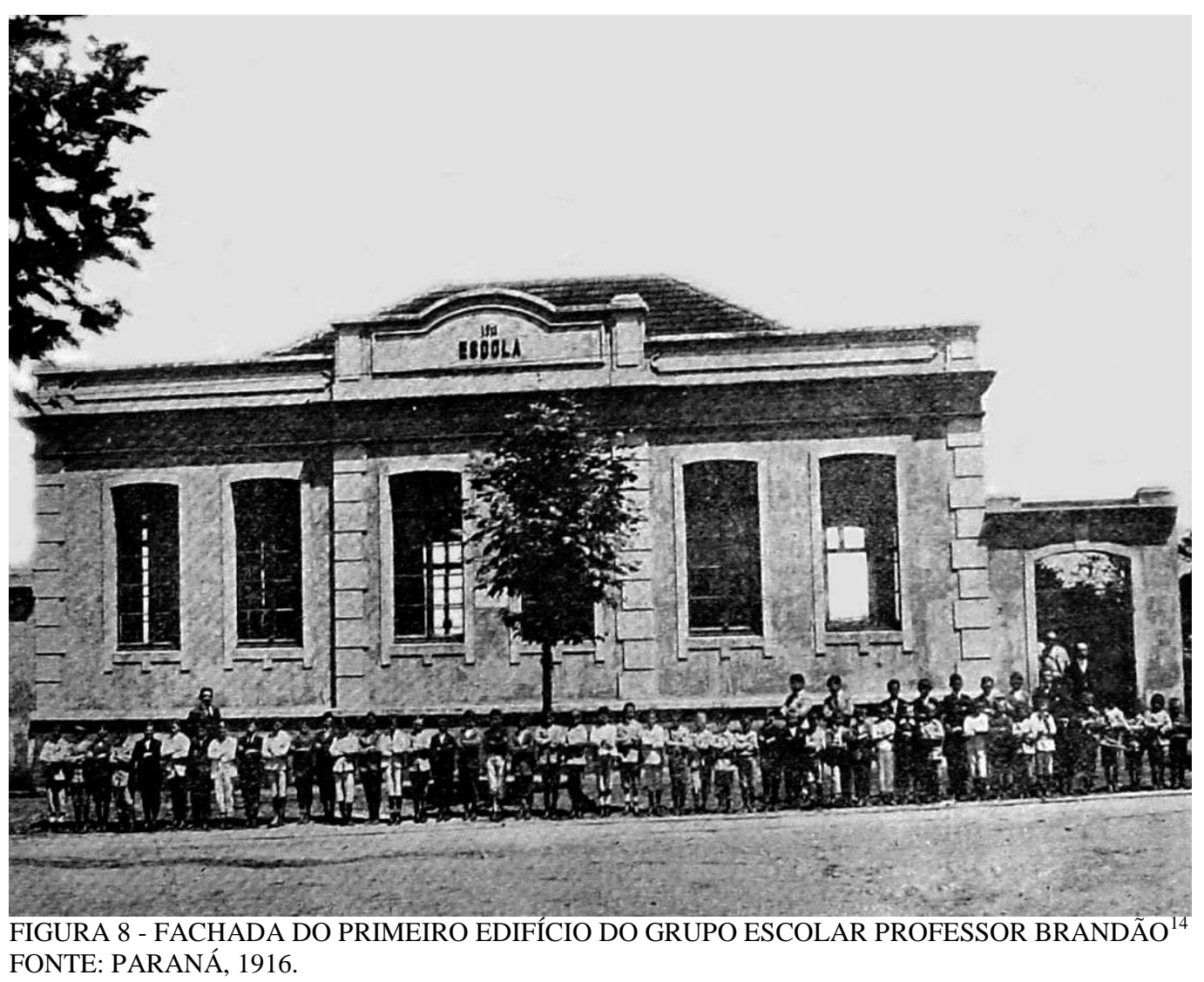

O primeiro edifício-escola destinado ao Grupo Escolar Rio Branco (figura 9) foi considerado um dos mais belos de Curitiba entre os seus similares. Projetado por Ângelo Bottiechia, desenhista da Secção de Obras e Viação do Estado do Paraná, o edifício, construído na esquina da Rua Brigadeiro Franco com a Silva Jardim, foi inaugurado em 3 de abril de 1911 (PARANÁ, 1910b, p. 23). Tinha como características principais os frontões quadriculares, marcadamente em estilo semiclássico, que indicavam os acessos principais: um pela Brigadeiro Franco, outro pela Silva Jardim, provavelmente para a entrada diferenciada dos meninos e das meninas. $O$ porão alto conferia destaque especial à volumetria de seu único pavimento e às suas fachadas: frontal e lateral.

As técnicas adotadas na construção do projeto arquitetônico de Bottiechia foram semelhantes às empregadas em todos os outros edifícios-escola, ou seja: alvenaria de tijolos de barro, janelas constituídas com caixilhos de cedro, vidro e venezianas, forros, assoalhos de pinho, assim como o madeiramento do telhado, cobertura de telhas

\footnotetext{
${ }^{14}$ Inaugurado no ano de 1911, à Rua Graciosa (atual Av. João Gualberto), foi projetado para ter inicialmente 2 salões $(7,40 \times 10,5)$ e um vestíbulo comum $(4,70 \times 2,40)$. (PARANÁ, 1910b, p. 25). Em 1965, durante o governo Ney Braga, o grupo foi demolido, dando lugar a um novo prédio, inaugurado em 02 de agosto de 1968 pelo então governador Paulo Pimentel.
} 
francesas, fundação direta de alvenaria de pedras, revestimento com argamassas de cal e areia e, por fim, a pintura do edifício, sendo as paredes a cola com requadros e o madeiramento das janelas e portas a óleo com três mãos. (PARANÁ, 1910b, p. 124-125)

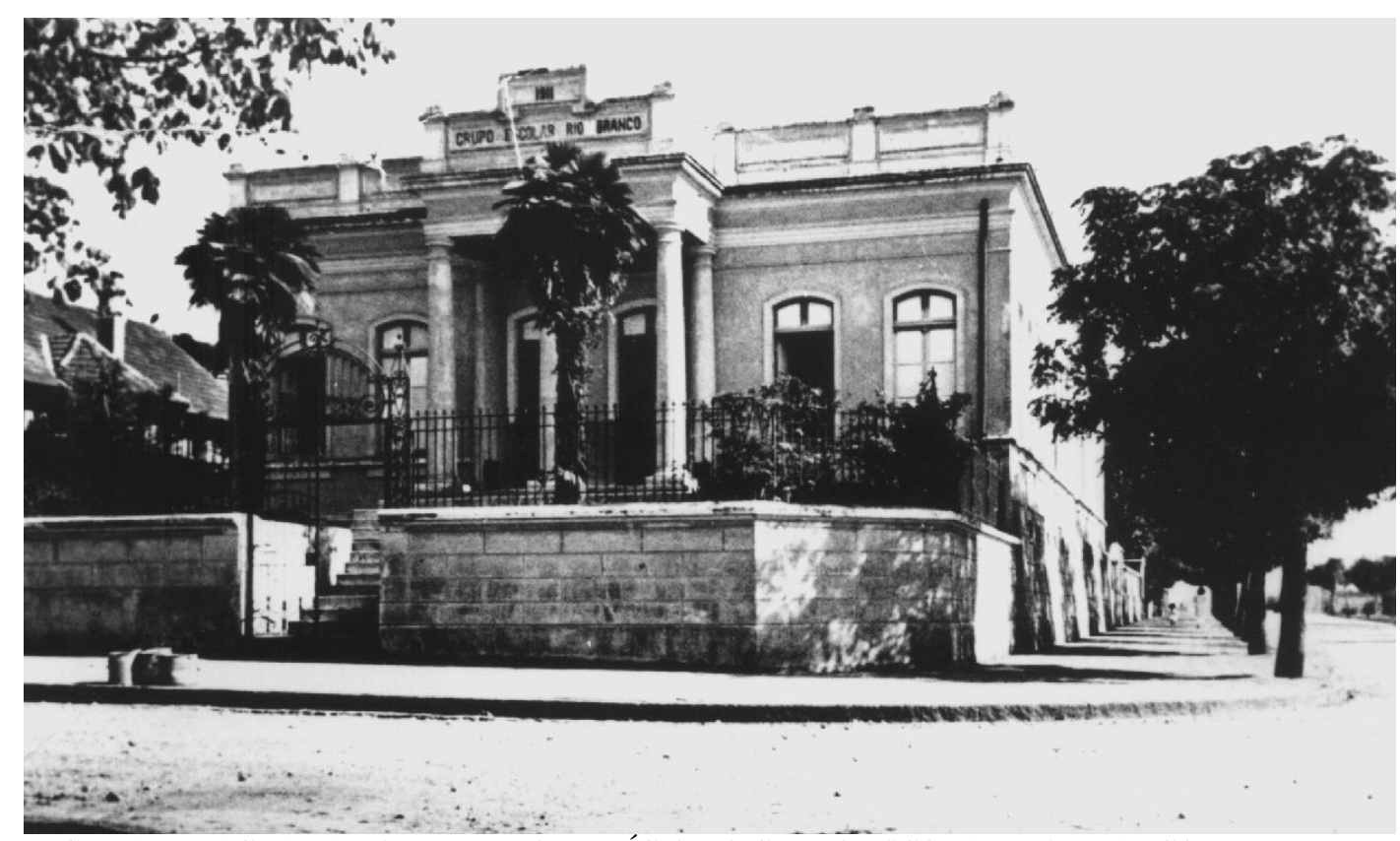

FIGURA 9 - FACHADA DO PRIMEIRO EDIFÍCIO DO GRUPO ESCOLAR RIO BRANCO FONTE: Fundo Casa da Memória

A leitura da planta baixa do Rio Branco (figura 10) indica que esse edifício era composto por quatro salões, ${ }^{15}$ tendo cada um a superfície de $9,9 \mathrm{~m}^{2}$, fazendo parte, ainda, de seu projeto, dois saguões, um para cada grupo de duas salas. O gradil de ferro, colocado somente no trecho correspondente à projeção frontal, tinha a função de separar o edifício-escola do espaço exterior da rua. Outra característica deste edifício é a área destinada ao recreio dos alunos, que, como se pode perceber, estava restrita aos fundos do terreno, sem piso e muito menos qualquer tipo de cobertura que protegesse as crianças das intempéries.

\footnotetext{
${ }^{15}$ A abertura de uma porta que estabelece a comunicação interna das 4 salas de aulas e demais dependências do edifício é de 1917 (PARANÁ, 1918, p. 173).
} 


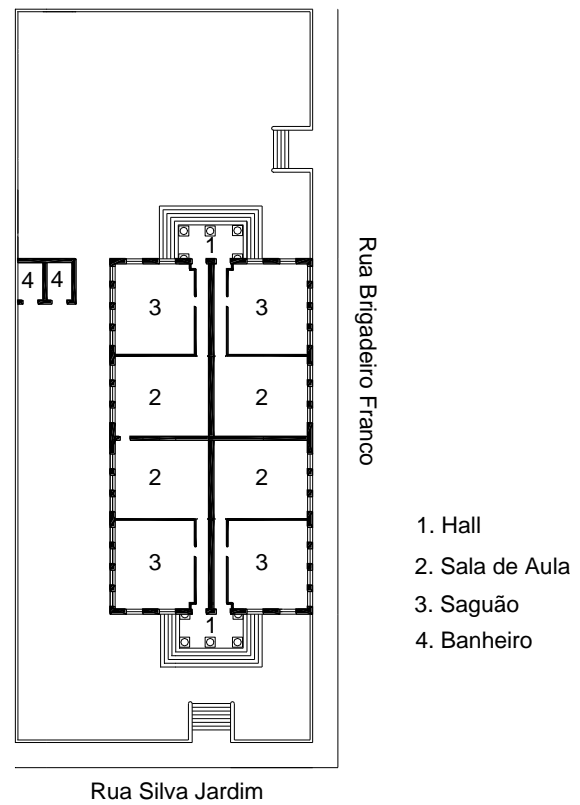

FIGURA 10 - PLANTA BAIXA DO PRIMEIRO EDIFÍCIO DO GRUPO ESCOLAR RIO BRANCO FONTE:Coordenadoria do Patrimônio - Secretaria de Administração do Estado do Paraná

Próximo ao Grupo Escolar Rio Branco encontra-se outra edificação, daquelas concebidas em 1910, que se destacou por sua monumentalidade: o primeiro edifício do Grupo Escolar 19 de Dezembro. Fundado em 1911, na antiga Rua Montevidéu (atual Desembargador Motta), tinha no seu projeto original dois corpos separados (figura 11) por um espaço de 10 metros.

Cada corpo é constituído por dois salões de $11 .{ }^{\mathrm{m}} 00 \times{ }^{\mathrm{m}} \quad{ }^{\mathrm{m}} 10$ correspondente a cada um deles, um vestíbulo de $3 .{ }^{\mathrm{m}} 00 \times 3 .{ }^{\mathrm{m}} 00$, uma saleta central de $3 .^{\mathrm{m}} 00 \times 3 .{ }^{\mathrm{m}} 00$ para o professor, e um gabinete para latrina e mictório, com $3{ }^{\mathrm{m}} 00 \times 3{ }^{\mathrm{m}} 00$. Os salões das classes e compartimentos acessórios são completamente independentes uns dos outros. Amplamente ventilados e iluminados satisfazem a todas as regras pedagógicas exigidas, tendo até um cubo de ar, por aluno que em média poderá freqüentar cada classe, superior ao que determinam os tratados que se preocupam com o importante assunto da higiene escolar (PARANÁ, 1910c, p. 40) 


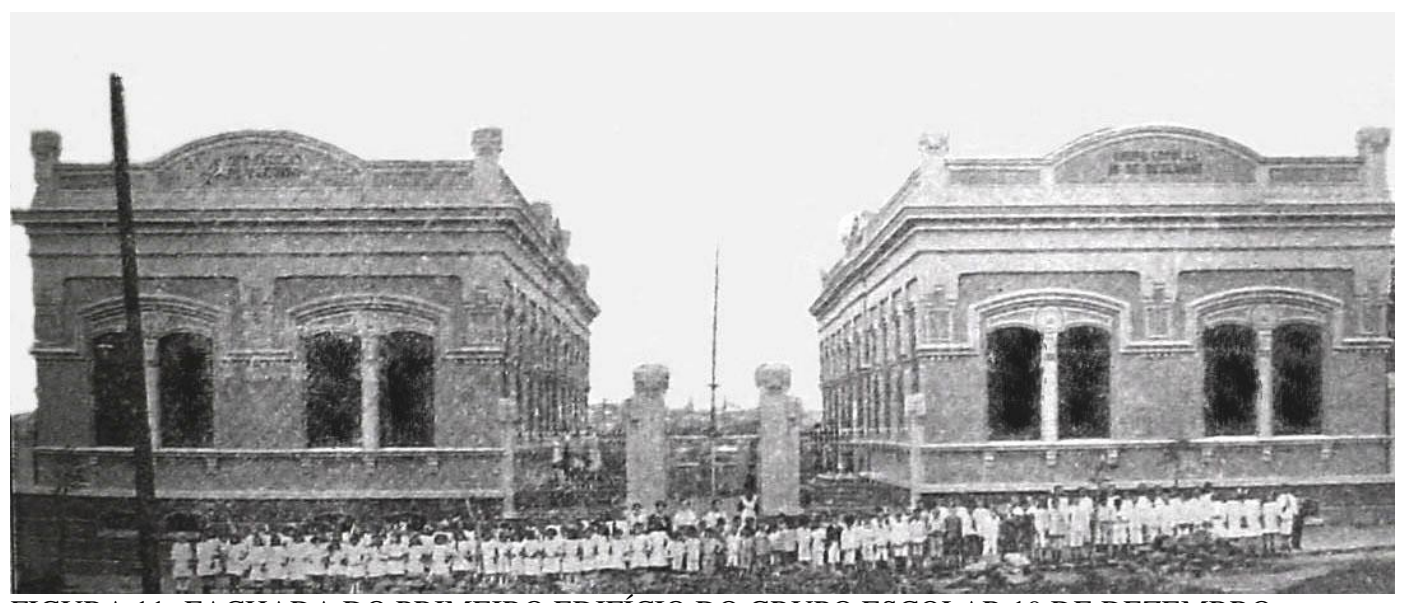

FIGURA 11- FACHADA DO PRIMEIRO EDIFICIO DO GRUPO ESCOLAR 19 DE DEZEMBRO FONTE: PARANÁ,1916.

Esse foi um dos mais aprazíveis dentre os edifícios-escola marcado por uma linguagem que, mesmo empregando nas fachadas alguns poucos elementos decorativos que lembravam o Art Nouveau, não conseguiu fugir do estilo arquitetônico eclético segundo os moldes europeus. Prevendo o acesso frontal para o seu espaço interior e, logo após, o lateral para a entrada nas salas de aula, esse projeto se destacava pela riqueza de harmonia no jogo de volumes da fachada, presente nos dois blocos. A separação entre os espaços de ensino para meninos e meninas, interligados apenas por um pequeno pátio que servia de recreio aberto ficava nítida. Ademais, compunha seu conjunto arquitetônico um muro de fechamento que se prolongava por volta do terreno.

Outro edifício-escola que se insere no cenário urbano curitibano do início do século XX, foi o Grupo Escolar Professor Cleto. Construído, também em 1911, no bairro do Alto São Francisco, na confluência da Rua Visconde de Nácar com o Boulevard Santa Matilde (atual Rua Júlia da Costa). Originalmente, segundo o que determinava seu contrato de construção, era constituído por quatro salões contíguos, tendo cada um as dimensões de 9m,30 x 6m,50 (PARANÁ, 1910b, p. 40). O Professor Cleto compunha, portanto, juntamente com o 19 de Dezembro e o Rio Branco, o conjunto de grupos escolares existentes até então na cidade com plantas para quatro salas (figura 12). 


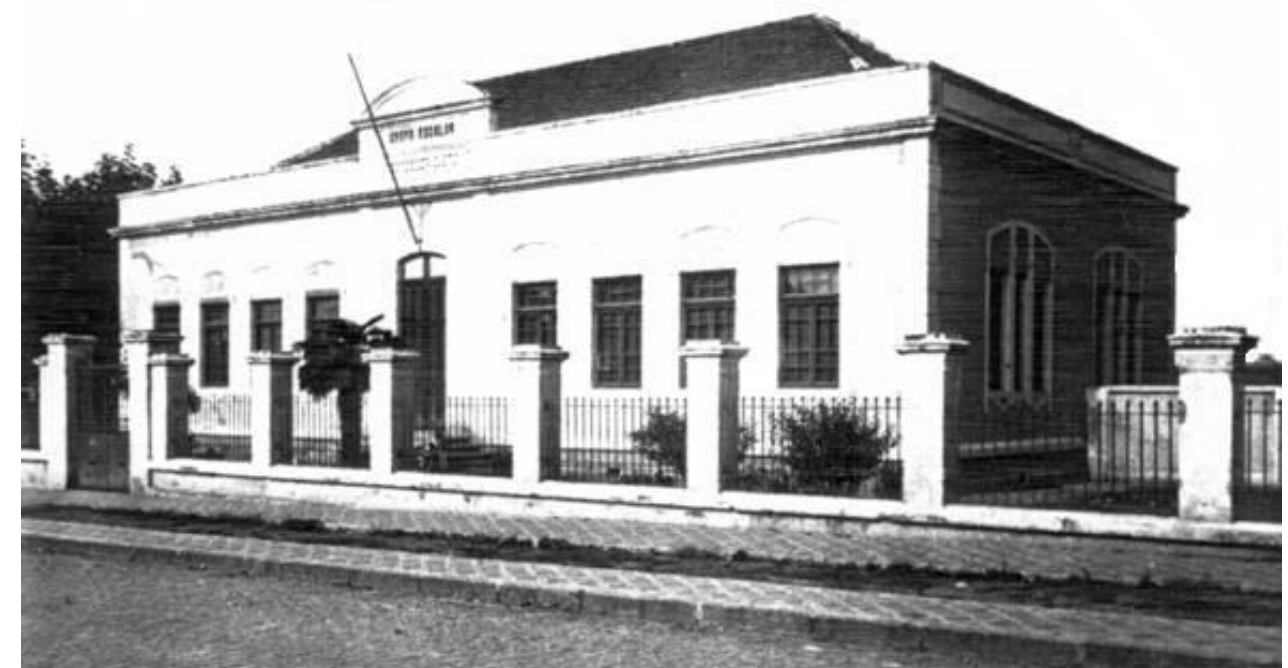

FIGURA 12 - FACHADA DO PRIMEIRO EDIFÍCIO DO GRUPO ESCOLAR PROFESSOR CLETO FONTE: Fundo Casa da Memória

$\mathrm{Na}$ ocasião de sua instalação, não foi uma preocupação inicial tratar do espaço recreativo dos alunos, inexistindo, conforme se observa na planta original do Professor Cleto, qualquer identificação de recreio interno ou pátio. Os momentos de descontração entre os intervalos das atividades didáticas estavam circunscritos ao espaço externo ao edifício (figura 13) rigidamente delimitado pelo gradil e muro de fechamento, isso quando o clima curitibano permitia. 


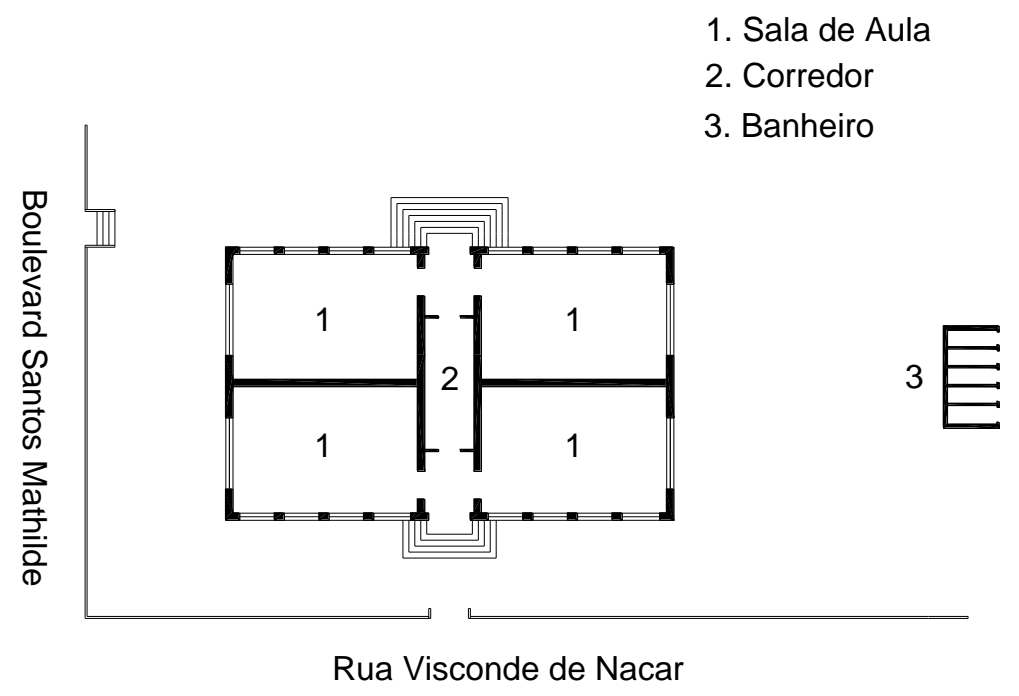

FIGURA 13 - PLANTA BAIXA DO PRIMEIRO EDIFÍCIO DO GRUPO PROFESSOR CLETO FONTE: Coordenadoria do Patrimônio - Secretaria da Administração do Estado do Paraná

Em 1937, o Professor Cleto foi totalmente reconstruído e perdeu as suas formas arquitetônicas originais, ficando apenas na memória daqueles que o conheceram a lembrança do pequeno prédio retangular da Visconde de Nácar.

As reflexões até aqui apresentadas nos levam a inferir que foram raras as exceções, dentre os primeiros edifícios dos grupos escolares de Curitiba, que preservaram suas principais características construtivas e espaciais. Alguns já não existem por decisões governamentais desastrosas e mal explicadas pelo crescimento urbano e conseqüente aumento da demanda por uma educação pública primária. Essas decisões resultaram na desativação, demolição e mesmo substituição de alguns edifícios-escola que retratavam parte significativa do patrimônio histórico arquitetônico curitibano.

$\mathrm{O}$ conjunto dos próximos grupos refere-se àqueles que tiveram preservados alguns traços de seus projetos originais, mas que foram modificados a partir de reformas de ampliação e restauro ocorridas ao longo dos anos. Trata-se, pois, a seguir, dos Grupos Escolares Conselheiro Zacarias e Presidente Pedrosa.

O Grupo Escolar Conselheiro Zacarias, fundado em 1911 em prédio localizado na esquina das ruas Matadouro Velho, atual Itupava, com Boulevard Marechal Floriano, atual Ubaldino do Amaral, no bairro Alto da Glória, era composto, naquela época, por apenas duas salas onde funcionavam as aulas de $1^{\mathrm{a}}, 2^{\mathrm{a}}$ e $3^{\mathrm{a}}$ séries (PARANÁ, 1912, p.13). A configuração destas duas pequenas salas que mediam cada uma, $7,40 \mathrm{~m} \times 10,50 \mathrm{~m}$, mais um vestíbulo comum de 4,70m x 2,40 m (PARANÁ, 1911, p. 23), faz acreditar que se tratava de um semigrupo escolar, visto que não possuía as condições espaciais que lhe permitiriam oferecer um maior número de vagas (figura 14). 


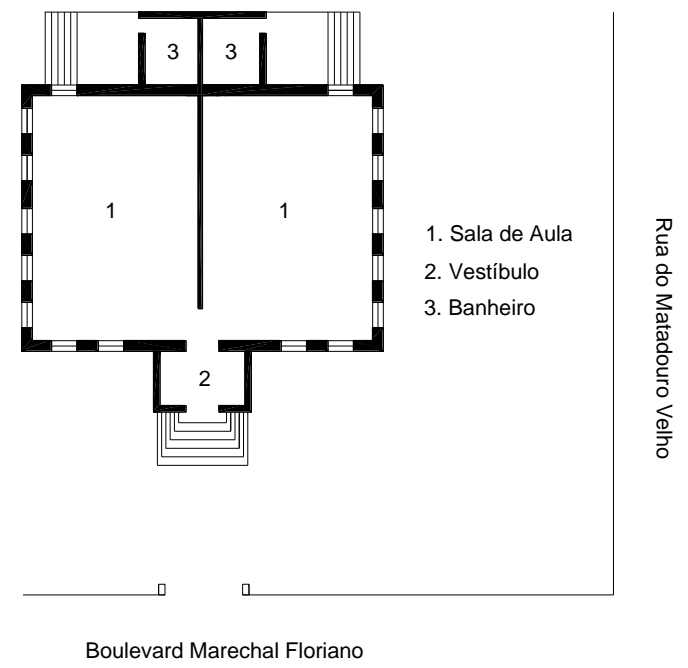

FIGURA 14 - PLANTA BAIXA DO GRUPO ESCOLAR CONSELHEIRO ZACARIAS

FONTE: Coordenadoria do Patrimônio - Secretaria de Administração do Paraná

Proporções semelhantes foram também utilizadas na construção do Grupo Escolar Presidente Pedrosa (figura 15), segundo o que consta no Relatório de Obras Públicas de 1910: "O edifício compreende dois salões de 7m,40 - 10m,50, tendo um vestíbulo comum de $4 \mathrm{~m}, 70-2 \mathrm{~m}, 00$ cada um, e está situado no quilometro 3 da estrada do Portão" (PARANÁ, 1910b, p. 41).

3 平

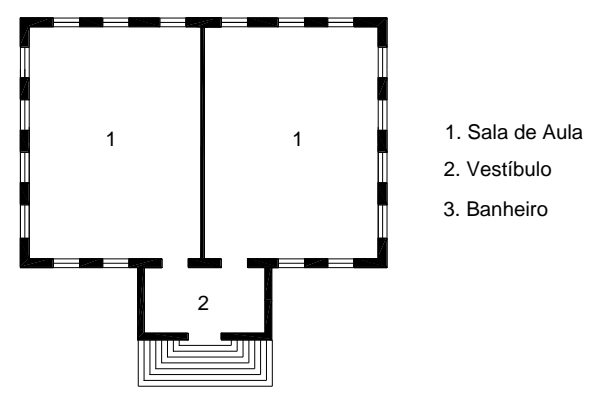

Estrada do Portão Km 3

FIGURA 15 - PLANTA BAIXA DO GRUPO ESCOLAR PRESIDENTE PEDROSA

FONTE: Coordenadoria do Patrimônio - Secretaria da Administração do Paraná

A simplicidade do espaço do Conselheiro Zacarias e do Presidente Pedrosa também foi predominante no desenho de suas fachadas (figuras 16 e 17), com quase nenhuma composição decorativa que permitisse identificar um estilo arquitetônico de escala monumental, não havendo qualquer preocupação em diferenciar seus tratamentos formais, optando-se pela mera padronização. A adoção desse procedimento de repetição 
do mesmo projeto para diferentes escolas era explicada por questões orçamentárias e pelos curtos espaços de tempo para a construção dos edifícios.

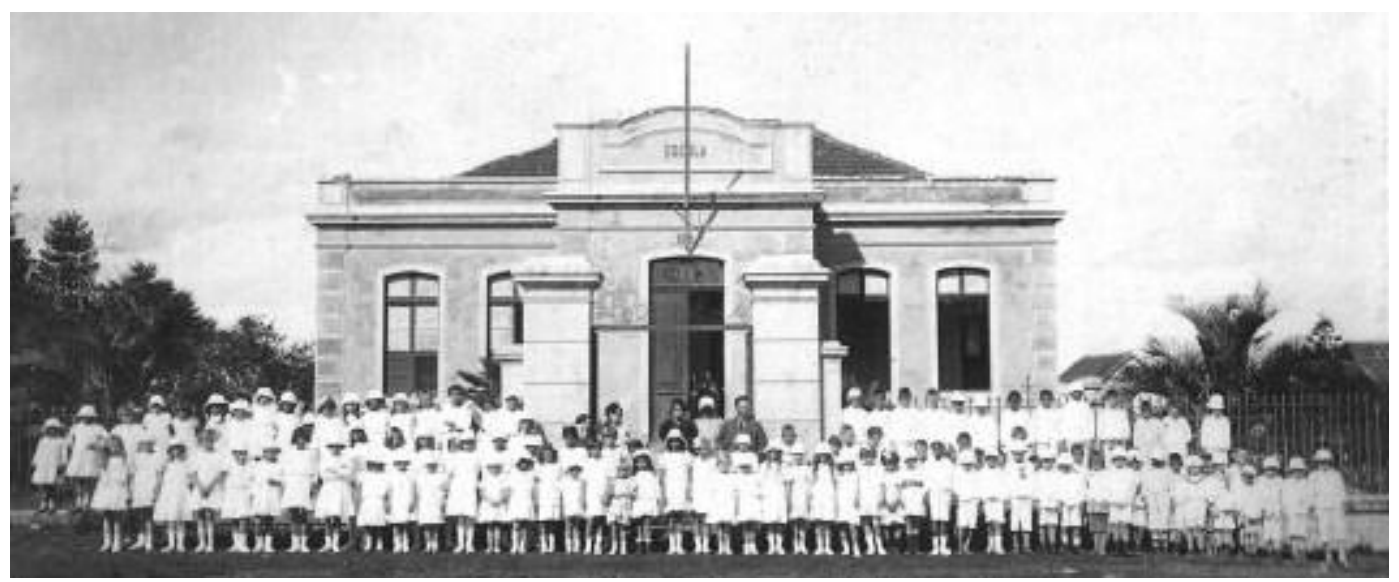

FIGURA 16 - FACHADA DO GRUPO ESCOLAR CONSELHEIRO ZACARIAS

FONTE: Coleção Lysimaco Ferreira da Costa - Fundo Casa da Memória

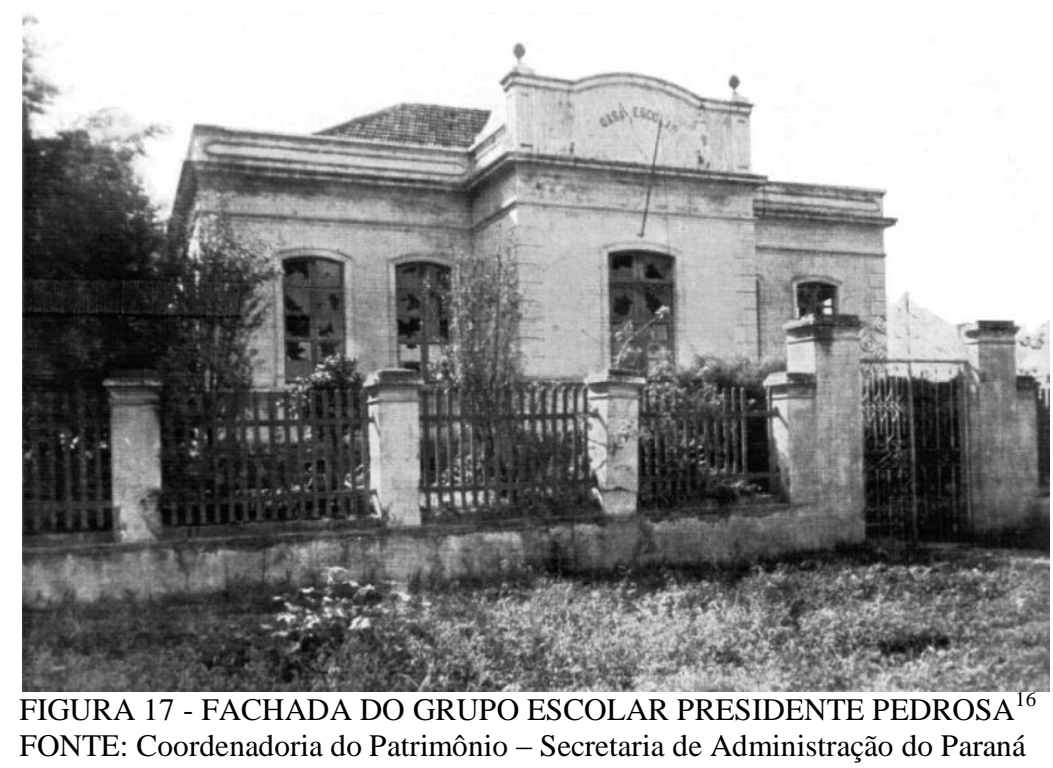

${ }^{16}$ Em 1937, o Presidente Pedrosa sofreu uma reforma geral que o levou a perder parte de seus traços originais: "[...] tinha quatro janelas de frente e uma porta no corpo central. Com a reconstrução, num só alinhamento, com seis janelas de frente e uma porta e quatro salas" (HISTÓRICO do Grupo Escolar Dr. Pedrosa - Portão. Curitiba: Arquivo do Grupo Escolar Dr. Pedrosa, 1937. Mimeog., p. 29). 
Durante a década de 1910, a reorganização das escolas primárias procurou seguir preceitos pedagógicos que englobavam a proposta de reorientação do ensino primário. A realidade paulista foi constantemente posta em destaque como experiência a ser observada com mais atenção. "É bem verdade que sem embargo da nova orientação, os nossos grupos escolares não se podem comparar com os do adiantado Estado de São Paulo, que dispõe do material técnico indispensável para a obtenção dos resultados ali acolhidos, além da competente administração do pessoal docente, exclusivamente preocupado com o ensino" (PARANÁ, 1915b, p. 25).

Esta exagerada admiração pelos grupos escolares paulistas ofuscava o olhar das autoridades de ensino paranaenses ao ponto de não perceberem o distanciamento que aqueles também possuíam do seu projeto discursivo quando da implantação da Escola Graduada no Estado de São Paulo, assunto já criteriosamente discutido por SOUZA (1998).

Nesse contexto, encontra-se a justificativa para contratação em 1920, do professor César Pietro Martinez, naquele momento diretor da Escola Normal de Pirassununga (a primeira do interior de São Paulo, fundada em 1894), para assumir o cargo de Inspetor Geral do Ensino no Estado do Paraná. Na sua passagem pelo Estado, Pietro Martinez tornou-se o principal responsável pelo salto qualitativo na organização do ensino ao providenciar, dentre outras ações, a divulgação de novos métodos de ensino nos grupos escolares e as palestras pedagógicas dedicadas aos professores e diretores de Curitiba, com o propósito de expor o pensamento em relação à reforma da instrução e quais eram os métodos modernos de ensino (PARANÁ, 1921, p. 91).

Ao examinar a realidade dos edifícios escolares da capital e do estado do Paraná, o novo Inspetor Geral de Ensino não economizou críticas ao que viu, alertando ao presidente do Estado, Caetano Munhoz da Rocha, a necessidade de se providenciar algumas medidas.

Um rápido exame dos prédios escolares do Estado, demonstra à saciedade quão longe estamos do que requerem os preceitos pedagógicos modernos e do que as necessidades do ensino reclamam. Nas construções escolares nem mesmo os detalhes podem ser menos desprezados para que possam aliar comodidades e conforto, economia e condições higiênicas. Os preceitos de arquitetura escolar foram por completo olvidados nas nossas construções. Algumas pequenas obras de captação têm sido feitas, restando ainda outras por fazer, não menos urgente e imprescindíveis (PARANÁ, 1921, p. 92).

Durante os anos que se seguiram, o cenário arquitetônico dos grupos escolares não seria modificado. Foi somente com a inauguração do Grupo Escolar D. Pedro II que se retomaram premissas da estética urbana e do caráter monumental destinado à construção de um grupo escolar da capital.

O D. Pedro II é o primeiro grupo escolar construído em dois pavimentos (figura 18) e projetado com as dependências necessárias para o seu funcionamento ideal, tais como, gabinete de diretor, sala de professor etc (PARANÁ,1928, p. 110). 

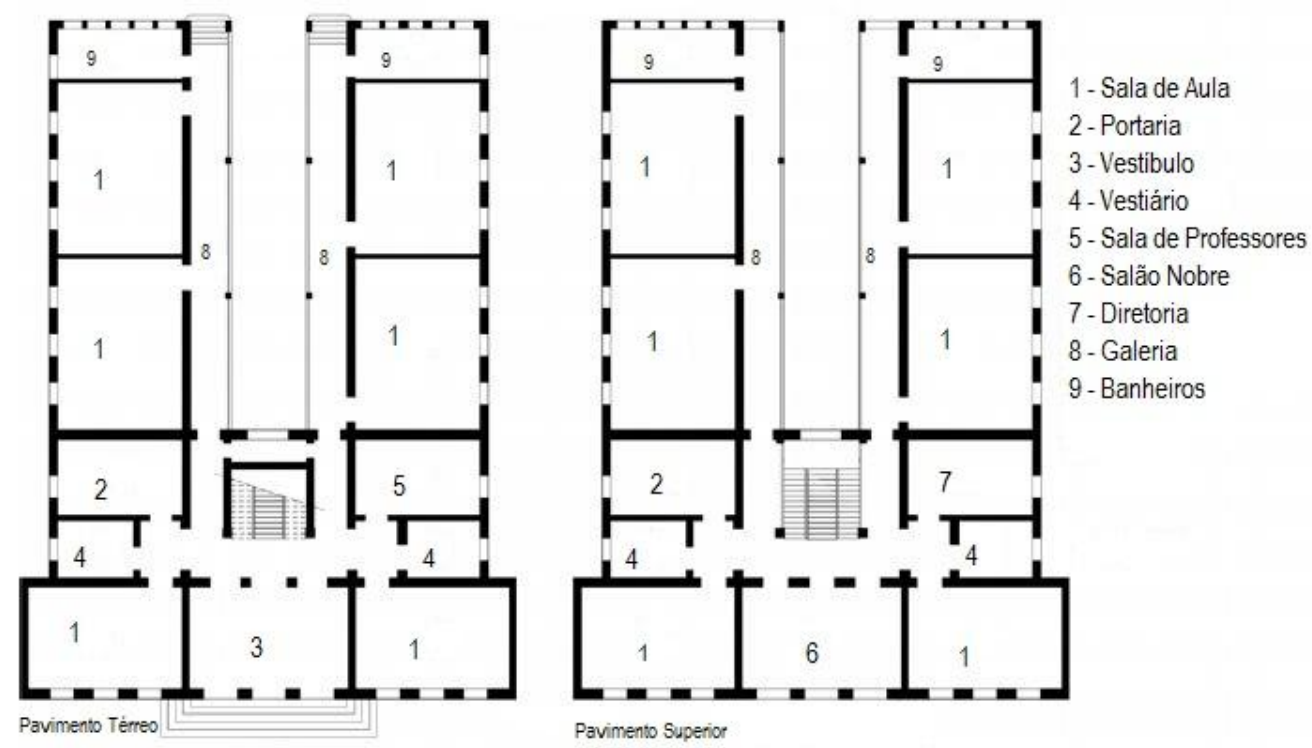

FIGURA 18 - PLANTA BAIXA DO EDIFÍCIO DO GRUPO ESCOLAR D. PEDRO II

FONTE: Coordenadoria do Patrimônio - Secretaria da Administração do Estado do Paraná

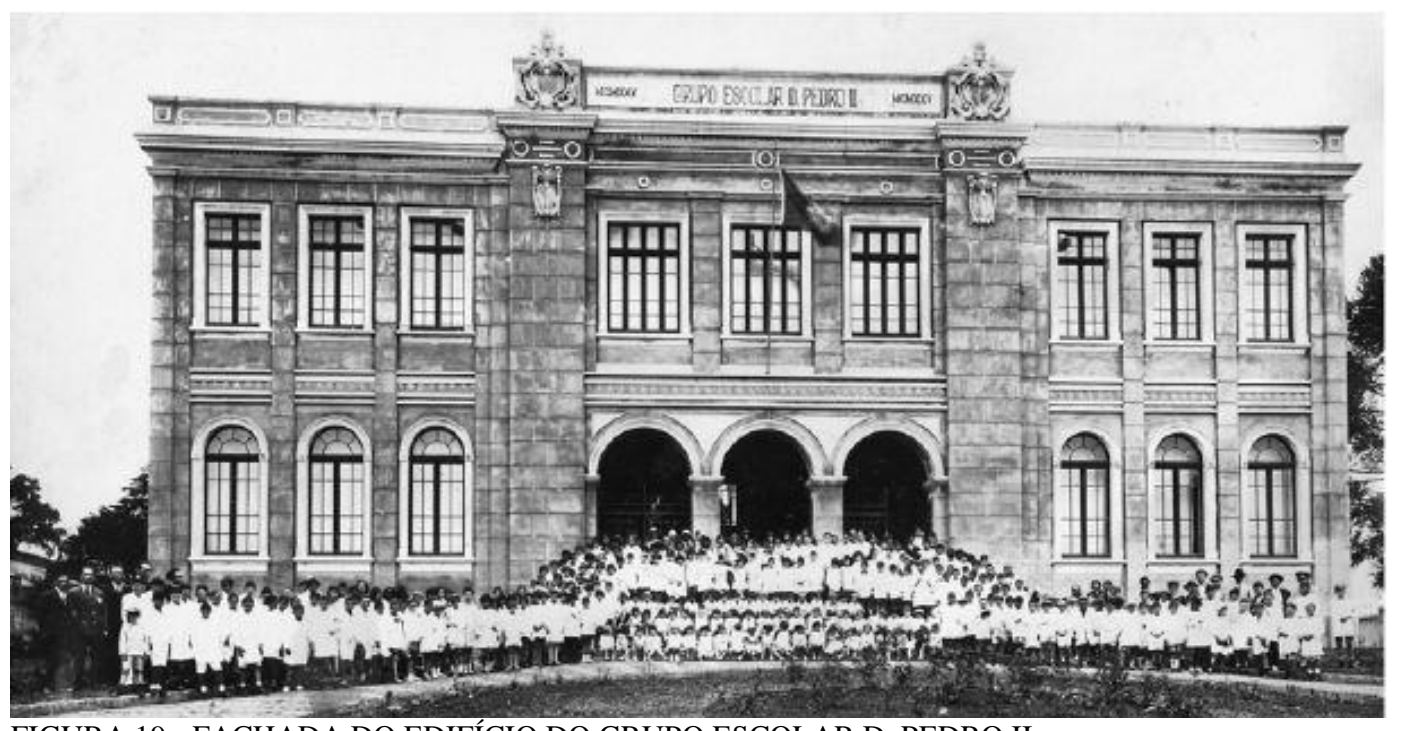

FIGURA 19 - FACHADA DO EDIFÍCIO DO GRUPO ESCOLAR D. PEDRO II

FONTE: Coordenadoria do Patrimônio - Secretaria da Administração do Estado do Paraná

O edifício desse grupo foi concluído em 1928 e, ainda hoje, distingue-se dentro da paisagem urbana da avenida Bispo Dom José, no bairro do Batel (figura 19). Sua fachada, ricamente ornamentada por um conjunto de elementos decorativos, vinculado a diversos repertórios estilísticos, que se identificam com a arquitetura eclética 
BENCOSTTA, M. L. A. Arquitetura e espaço escolar: reflexões ...

predominante em São Paulo no início do século XX, e o seu tratamento formal fazem lembrar muito de perto os projetos de edifícios-escola de 2 pavimentos planejados por Ramos de Azevedo ${ }^{17}$. Exemplo disso é a semelhança do traçado desse grupo com o do Grupo Escolar Rodrigues Alves, construído na avenida Paulista. A existência de 12 salas de aula no D. Pedro II, provavelmente resultado da demanda escolar, é um dado que o colocava ao lado do Grupo Escolar Modelo Dr. Xavier da Silva, distinguindo-se dos demais grupos escolares.

\section{Considerações Finais}

No Paraná, o processo de institucionalização dos grupos escolares, nas duas primeiras décadas do século $\mathrm{XX}$, foi um dos resultados da reorganização do ensino público no Estado. As mudanças, que não ficaram restritas à transposição didática $\mathrm{e}$ pedagógica, foram conduzidas no sentido de se pensar, debater e destinar espaços específicos para a escola primária.

Concordando com SOUZA (1998), esta institucionalização é uma das principais representações do plano republicano de modernização da sociedade e de civilização dos brasileiros. Dar origem aos grupos escolares, como modelo de escola racionalizada e padronizada, significava estar atento às necessidades de um projeto de integração social e política pensado como fundamentação para a estabilidade da República.

Em Curitiba, viu-se que nem todos os primeiros grupos escolares ocuparam locais de destaque na cena urbana. Vários deles não possuíam edifícios em proporções monumentais que merecessem, da retórica republicana, adjetivos laudatórios, tais como: templos ou palácios da instrução. Os espaços funcionais que a moderna pedagogia exigia, como gabinete para diretor, biblioteca, anfiteatro, laboratórios, secretaria, oficinas, pátios etc., também foram desconsiderados. As únicas exceções neste aspecto foram os grupos escolares Dr. Xavier da Silva e D. Pedro II.

Ainda assim, é possível afirmar que a arquitetura e a configuração do espaço escolar curitibano a partir das primeiras construções de grupos escolares passaram a contribuir para a elaboração de representações sociais que foram incorporadas pelos moradores da cidade. Como percepções coletivas, essas representações permitiam reconhecer o grupo escolar como uma inovação que, por sua vez, evidenciava os sinais de uma nova ordem: a republicana.

\footnotetext{
${ }^{17}$ Segundo CARVAlHO (2000, p. 15), "Francisco de Paula Ramos de Azevedo teve um papel significativo em seu tempo para a arquitetura paulista. Os edifícios cujos projetos nasceram em seu escritório trouxeram, além da novidade de suas formas, outra contribuição: a dos princípios projetuais segundo os quais foram concebidos."
} 
BENCOSTTA, M. L. A. Arquitetura e espaço escolar: reflexões ...

\section{Fontes}

A REPÚBLICA. 9 de novembro de 1904.

CONVITE. C. E. "Dr. Xavier da Silva”. 100 Anos dedicados à educação.

ESCOLA Dr. Xavier da Silva. Jubileu de Diamantes. 75 anos - 1903 - 19 de Dezembro 1978. Curitiba: [s.n.], 1978. Mimeog.

GAZETA do Povo, 6 de junho de 2003.

HISTÓRICO da Escola Tiradentes. Curitiba: Arquivo do Colégio Tiradentes, 1975. Mimeog.

HISTÓRICO do Grupo Escolar Dr. Pedrosa - Portão. Curitiba: Arquivo do Grupo Escolar Dr. Pedrosa, 1937. Mimeog.

PARANÁ. Governador (1895: Silva). Relatorio apresentado ao Exmo. Sr. Dr. Francisco Xavier da Silva, Governador do Estado do Paraná, pelo Dr. João Baptista da Costa Carvalho Filho, Secretario de Obras Publicas e Colonisação em 28 de outubro de 1895.Corityba: Imprensa Paranaense, 1896.

PARANÁ. Governador (1901: Silva). Mensagem apresentada ao Congresso Legislativo do Estado na 2. ${ }^{a}$ Sessão da $5 .^{a}$ Legislatura, no dia $1 .^{\circ}$ do corrente, pelo Exmo. Sr. Dr. Francisco Xavier da Silva. Curityba: Typ. d’A República, 1901.

PARANÁ. Governador (1903: Silva). Relatorio apresentado ao Exmo. Sr. Dr. Francisco Xavier da Silva, Governador do Estado do Paraná, pelo Bacharel Arthur Pedreira de Cerqueira, Secretario d'Estado dos Negocios e Obras Publicas e Colonisação em 31 de Dezembro de 1903. Corityba: Typ. e Lith. "Impressora Paranaense", 1904a.

PARANÁ. Governador (1904: Silva). Mensagem apresentada pelo Exmo. Snr. Dr. Francisco Xavier da Silva - Governador do Estado - ao Congresso Legislativo na $1^{o}$ Sessão Ordinaria de $7^{\circ}$ Legislatura, em $1^{\circ}$ de fevereiro de 1904. Curityba: Typ. d’A República, 1904b.

PARANÁ. Governador (1904: Silva). Relatorio apresentado ao Exmo. Dr. Secretário do Interior, Justiça e Instrucção Pública pelo Dr. Reinaldo Machado, Director Geral Interino da Instrucção Pública do Estado em 31 de dezembro de 1904. Curytiba: Typ. e Lith. Impressora Paranaense, 1905.

PARANÁ. Governador (1906: Lima). Relatorio apresentado ao Exmo. Sr. Dr. Bento José Lamenha Lins, D.D. Secretario do Interior, Justiça e Instrucção Publica, pelo Dr. Arthur 
BENCOSTTA, M. L. A. Arquitetura e espaço escolar: reflexões ...

Pedreira de Cerqueira, Director Geral de Instrucção Publica em 31 de Dezembro de 1906. Curityba: Annibal Rocha \& Cia, 1907a.

PARANÁ. Governador (1907: Lima). Mensagem ao Congresso Legislativo do Estado do Paraná dirigida pelo Dr. Vicente Machado da Silva Lima, Presidente do Estado ao installar-se na $2 .^{a}$ Sessão da $8 .^{a}$ Legislatura em $1 .^{\circ}$ de Fevereiro de 1907. Curityba: Annibal Rocha \& Cia, 1907b.

PARANÁ. Governador (1907: Lima). Relatorio apresentado ao Sr. Dr. Arthur Pedreira de Cerqueira, Director Geral da Instrucção Publica do Estado, pelo Dr. Laurentino de Azambuja, Delegado Fiscal da 1. ${ }^{a}$ Circumscripção Escolar, em 27 de Dezembro de 1907. Corityba: Typ. d’A República, 1908.

PARANÁ. Governador (1910: Silva).Relatorio apresentado ao Exmo. Sr. Coronel Luiz Antonio Xavier, Secretario do Interior, Justiça e Instrução Publica pelo Dr. Jayme Dormund dos Reis, Director Geral Interino de Instrucção Publica do Estado, Em 24 de Novembro de 1909. Curytiba: TYP. d' A República, 1910a.

PARANÁ. Governador (1910: Silva). Relatorio apresentado ao Exmo. Sr. Dr. Francisco Xavier da Silva, Presidente do Estado, em 31 de dezembro de 1910, pelo Bacharel Claudino Rogoberto Ferreira dos Santos, Secretario d'Estado dos Negocios de Obras Publicas e Colonização. Curityba: Typ. d’A República, 1910b

PARANÁ. Governador (1910: Silva). Relatorio apresentado ao Exmo. Sr. Dr. Francisco Xavier da Silva, Presidente do Estado, Em 31 de dezembro de 1910, pelo Bacharel Claudino Rogoberto Ferreira dos Santos, Secretario d’Estado dos Negocios de Obras Publicas e Colonização. Contracto para construcção do Grupo Escolar nesta Capital entre as ruas Brigadeiro Franco e Silva Jardim.Curityba: Typ. d’A República, 1910 b.

PARANÁ. Governador (1911: Silva). Relatorio apresentado ao Exmo. Sr. Dr. Francisco Xavier da Silva, Presidente do Estado, em 31 de Dezembro de 1911, pelo Bacharel Claudino Rogoberto Ferreira dos Santos, Secretario d'Estado dos Negocios de Obras Publicas e Colonização. Curityba: Typ. d'A Republica, 1911.

PARANÁ. Governador (1912: Silva). Mensagem dirigida ao Congresso Legislativo do Estado do Paraná pelo Dr. Francisco Xavier da Silva, Presidente do Estado, ao installar-se a primeira sessão da 11. ${ }^{a}$ Legislatura em 2 de fevereiro de 1912. Curityba: Typ. d'A República, 1912.

PARANÁ. Governador (1913: Albuquerque). Relatorio apresentado ao Exmo. Snr. Dr. Carlos Carlos Cavalcanti de Albuquerque, Presidente do Estado do Paraná pelo Secretario de Negócios de Obras Publicas, Terras e Viação, Dr. Marins Alves de Camargo. Curityba: Impressora Paranaense, 1913a. 
BENCOSTTA, M. L. A. Arquitetura e espaço escolar: reflexões ...

PARANÁ. Relatorio apresentado ao Exmo. Snr. Dr. Marins Alves de Camargo, Secretario do Interior, Justiça e Instrucção Publica, pelo Dr. Claudino Rogoberto Ferreira dos Santos, Director Geral da Instrucção Publica. Coritiba: Typ. do Diario Official, 1913b.

PARANÁ. Governador (1915: Albuquerque). Relatorio apresentado ao cidadão Dr. Claudino Rogoberto Ferreira dos Santos, Secretario d'Estado dos Negocios do Interior, Justiça e Instrucção Publica, pelo Dr. Francisco Ribeiro de Azevedo Macedo, Director Geral da Instrucção Publica em 31 de dezembro de 1914. Curityba: Typ. do Diario Oficial, 1915a.

PARANÁ. Governador (1915: Albuquerque). Mensagem dirigida ao Congresso Legislativo do Estado do Paraná pelo Exmo. Sr. Dr. Carlos Cavalcanti de Albuquerque, Presidente do Estado, ao installar-se a $2 .{ }^{a}$ Sessão da $12{ }^{a}{ }^{a}$ Legislatura em $1 .{ }^{\circ}$ de Fevereiro de 1915. Curityba: Typ. d’A República, 1915b.

PARANÁ. Governador (1916: Camargo). Relatorio apresentado ao Exmo. Snr. Dr. Affonso Alves de Camargo, Presidente do Estado, pelo Sr. Dr. Enéas Marques dos Santos, D. D. Secretario de Estado dos Negocios do Interior, Justiça e Instrucção Publica em 31 de dezembro de 1916. Curityba, Typ. d`A República, 1916.

PARANÁ. Governador (1917: Camargo). Relatorio apresentado ao Exmo. Snr. Dr. Affonso Alves de Camargo, Presidente do Estado, pelo Dr. Enéas Marques dos Santos, Secretario d'Estado dos Negocios do Interior, Justiça e Instrucção Publica, Em 31 de Dezembro de 1917. Coritiba: Typ. d’A República, 1917a.

PARANÁ. Governador (1917: Camargo). Relatorio apresentado ao Exmo. Snr. Dr. Enéas Marques dos Santos, Secretario do Interior, Justiça e Instrucção Publica, pelo Delegado do Ensino e Inspector Escolar Interino da Capital, Candido Natividade da Silva, em 31 de Dezembro de 1917. Coritiba: Typ. d’A República, 1917b.

PARANÁ. Governador (1917: Camargo). Relatorio apresentado ao Exmo. Snr. Dr. Affonso Alves de Camargo, Presidente do Estado, pelo Dr. Caetano Munhoz da Rocha, Secretario d'Estado dos Negocios da Fazenda, Agricultura e Obras Publicas, em 31 de dezembro de 1918. Exercicio 1917 - 1918 - Primeira Parte. Coritiba: Typ. d’A República, 1918.

PARANÁ. Governador (1920: Rocha). Mensagem dirigida ao Congresso Legislativo do Estado pelo Dr. Affonso Alves de Camargo, Presidente do Estado do Paraná ao installar-se a primeira Sessão da $15 .^{a}$ Legislatura em $1 .{ }^{\circ}$ de Fevereiro de 1920. Curityba: Typ. d’A Republica, 1920. 
BENCOSTTA, M. L. A. Arquitetura e espaço escolar: reflexões ...

PARANÁ. Governador (1921: Rocha). Mensagem dirigida ao Congresso Legislativo pelo Dr. Caetano Munhoz da Rocha, Presidente do Estado, ao installar-se a 2. ${ }^{a}$ Sessão da 15. ${ }^{a}$ Legislatura. Curityba, 1. ${ }^{\circ}$ de Fevereiro de 1921. Curityba: [s.n.], 1921.

PARANÁ. Governador (1922: Rocha). Mensagem dirigida ao Congresso Legislativo pelo Dr. Caetano Munhoz da Rocha, Presidente do Estado, ao installar-se a primeira sessão da 16. ${ }^{a}$ Legislatura. Curityba: $1 .^{\circ}$ de fevereiro de 1922. Curityba: [s.n.], 1922.

PARANÁ. Governador (1925: Rocha). Relatório da Secretaria Geral do Estado do Paraná apresentado a sua Excellencia, o senhor doutor Caetano Munhoz da Rocha, digníssimo Presidente do Estado, por Alcides Munhoz, Secretario Geral do Estado, referente aos serviços do exercício financeiro de 1924 - 1925. Curityba, 31 de Dezembro de 1925. Corityba: Livraria Mundial, 1925.

PARANÁ. Governador (1928: Rocha). Mensagem dirigida ao Congresso Legislativo pelo Dr. Caetano Munhoz da Rocha, Presidente do Estado, ao installar-se a primeira sessão da 19. ${ }^{a}$ Legislatura. Curityba: 1. ${ }^{\circ}$ de fevereiro de 1928. Curytiba: [s.n.], 1928.

PARANÁ. Governador (1929: Camargo). Mensagem apresentada ao Congresso Legislativo do Estado do Paraná, pelo Presidente Dr. Affonso Alves de Camargo ao installar-se a 2. ${ }^{a}$ sessão da 19. ${ }^{a}$ Legislatura. Curityba, 1. ${ }^{a}$ de Fevereiro de 1929. Curityba: [s.n.], 1929.

REGULAMENTO da Directoria Geral de Saúde Publica do Estado do Paraná. Coritiba: [s.n.]., 1929.

\section{Referências}

BOTO, C. A Escola do Homem Novo. Entre o Iluminismo e a Revolução Francesa. São Paulo: Editora da Unesp, 1996.

BOUDON, P. Sur l'espace architecturale. Paris: P. Dunod, 1971.

CARVAlHO, J. M. de. A Formação das Almas. O Imaginário da República no Brasil. São Paulo: Cia das Letras, 1990.

CHARTIER, R. The Edge of the Cliff. History, Language and Pratices. Baltimore/London: The Johns Hopkins University Press. 1997.

CHING, F. D. K. Arquitectura. Forma, Espacio y Orden. México: Ediciones Gili, 1996.

ESCOLANO, A. La arquitectura como programa. Espacio - escuela y curriculum. Historia de La Educación. Vol. XII - XIII (1993 - 94), p. 97 - 120.

FARIA FILHO, L. M. de. Dos Pardieiros aos Palácios. Cultura Escolar e Urbana em Belo Horizonte na Primeira República. Passo Fundo: Editora da UPF, 2000.

\& VIDAL, D. G. Os Tempos e os Espaços Escolares no processo de institucionalização da Escola Primária no Brasil. Revista Brasileira de Educação. nº 14 mai/jun/jul/ago. 2000.

FOUCAULT, M. Vigiar e Punir. Nascimento da prisão. Petrópolis: Vozes, 1983. 
BENCOSTTA, M. L. A. Arquitetura e espaço escolar: reflexões ...

GAILLARD, J.-M. Les Victoires de Jules Ferry. In: Mille ans d'école: de Charlemagne à Claude Allègre. Les Collections de l'Histoire. n.. 6, Oct/1999.

GAULUPEAU, Y.; ROZINOER, C.; LAMIRAUD, T. Une histoire de l'école. L'espace de la classe. Textes et Documents pour la classe. N. 808, 15-31 jan. 2001.

HOBSBAWM, Eric. Sobre História. São Paulo: Cia das Letras, 1998.

IWAYA, Marilda. Palácio da Instrução: representações sobre o Instituto de Educação do Paraná Professor Erasmo Pilotto (1940-1960). Dissertação (Mestrado) - Programa de Pós-Graduação em Educação da Universidade Federal do Paraná, 2001.

MARQUES, V. R. B. A Medicalização da Raça: médicos, educadores e discurso eugênico. Campinas: Editora da Unicamp, 1994.

MONARCHA, C. Arquitetura Escolar Republicana: a Escola Normal da Praça e a construção de uma imagem de criança. In: HISTÓRIA Social da Infância no Brasil. 2. ed. São Paulo: Cortez, 1999.

MORENO, J. C. Inventando a escola, inventando a nação: discursos e práticas em torno da escolarização paranaense (1920-1927). Dissertação (Mestrado) - Programa de PósGraduação em Educação da Universidade Federal do Paraná, 2003.

OLIVEIRA, M. C. M. O Grupo Escolar Dezenove de Dezembro: História e Organização. In: I CONGRESSO BRASILEIRO DE HISTÓRIA DA EDUCAÇÃO, 1., 2000, Rio de Janeiro. Anais ... Rio de Janeiro: [s.n.], 2000. 1 CD-ROM.

PROJETO 100 anos Xavier. Manuscrito, 2003.

SOUZA, R. F.. \& BENCOSTTA, M. L. A. et al. Memórias da Educação. Campinas (1850-1960). Campinas: Editora da Unicamp, 1999.

- Templos de Civilização. A implantação da Escola Primária Graduada no Estado de São Paulo (1890 - 1910). São Paulo: Editora da Unicamp, 1998.

et al. O Legado Educacional do Século XIX. Araraquara: UNESP - F. C. L. , 1998.

STAROBINSKY, J. 1789: Os emblemas da razão. São Paulo: Cia. das Letras, 1988.

TRINDADE, E. M. de C. Clotildes ou Marias. Mulheres de Curitiba na Primeira República. Curitiba: Fundação Cultural, 1996.

VIÑAO, A. Inovación pedagógica y nacionalidad científica. La escuela Graduada Pública en España (1898 - 1936). Madrid: Ediciones Akal, 1990.

WOLFF, M. C. de C. Ramos de Azevedo. São Paulo: Edusp, 2000.

ZEVI, B. Saber ver a Arquitetura. 5. ed. São Paulo: Martins Fontes, 2000.

Recebido em 12/04/2001 